\title{
Modulation of Presynaptic Action Potential Kinetics Underlies Synaptic Facilitation of Type B Photoreceptors after Associative Conditioning in Hermissenda
}

\author{
Chetan C. Gandhi and Louis D. Matzel \\ Department of Psychology, Program in Biopsychology and Behavioral Neuroscience, Rutgers University, Piscataway, \\ New Jersey 08854
}

\begin{abstract}
Descriptions of conditioned response generation in Hermissenda stipulate that the synaptic interaction between type $B$ and A photoreceptors should be enhanced after associative pairings of light and rotation. Although evidence from several laboratories has confirmed this assumption, the mechanism underlying this synaptic facilitation has not been elucidated. Here we report that in vitro conditioning (i.e., light paired with stimulation of vestibular hair cells) modifies the kinetics of presynaptic action potentials in the $\mathrm{B}$ photoreceptor in a manner sufficient to account for this synaptic facilitation. After paired training, we observed an increase in the duration of evoked action potentials and a decrease in the amplitude of the spike afterhyperpolarization in the B-cell. As previously reported, paired training also enhanced the excitability (i.e., input resistance and evoked spike rate) of the $\mathrm{B}$ photoreceptor. In a second experiment, simultaneous recordings were made in type B and A photoreceptors, and paired training was found to produce an increase in the amplitude of the IPSP in the A photoreceptor in response to an evoked spike in the B-cell. Importantly, there was no change in the initial slope of the postsynaptic IPSP in the A photoreceptor, suggesting that spike duration-independent mechanisms of neurotransmitter exocytosis or postsynaptic receptor sensitivity did not contribute to the observed synaptic facilitation. Perfusion of
\end{abstract}

In Hermissenda photoreceptors, two classes of neuronal facilitation have been described to result from associative training with paired presentations of light and rotation. One of these is manifest in the soma of B photoreceptors as an increase in membrane excitability and enhanced responsiveness to light (Crow and Alkon, 1980; West et al., 1982; Farley and Alkon, 1982, 1987; Matzel and Rogers, 1993; Rogers and Matzel, 1995). A second form of facilitation is expressed as the enhancement of the synaptic interaction between the B photoreceptor and its postsynaptic target, the A photoreceptor. This latter effect of associative conditioning is marked by an increase in the amplitude of mono-

Received June 3, 1999; revised Dec. 16, 1999; accepted Dec. 17, 1999.

This work was supported by the US Public Health Service National Institute of Mental Health Grant MH48387 and a Hoechst-Celanese Young Faculty Award to L.D.M. Thanks are extended to Sid Auerbach, Mark West, Andrew Talk, Isabel Muzzio, and Kathryn Muccino for comments during the development of this work and on an earlier version of this manuscript. We also thank Terry Crow for helpful advice regarding technical aspects of this work.

Correspondence should be addressed to Louis D. Matzel, Department of Psychology, Program in Biopsychology and Behavioral Neuroscience, Rutgers University, Busch Campus, Piscataway, NJ 08854. E-mail: matzel@rci.rutgers.edu.

Copyright (C) 2000 Society for Neuroscience $0270-6474 / 00 / 202022-14 \$ 15.00 / 0$ 4-aminopyridine (4-AP) mimicked a known effect of behavioral conditioning in that it specifically reduced the amplitude of the transient voltage-dependent $\mathrm{K}^{+}$current $\left(I_{\mathrm{A}}\right)$ in the $\mathrm{B}$-cell, but in addition, produced action potential broadening and synaptic facilitation that was analogous to that observed after in vitro conditioning. Finally, the effect of 4-AP on B-cell action potentials and on the postsynaptic IPSP in the A-cell was occluded by previous paired (but not unpaired) training, suggesting that the prolongation of the B-cell action potential by a reduction of $I_{\text {A }}$ was sufficient to account for the observed synaptic facilitation. The occlusion of the effects of 4-AP by paired training was not attributable to a saturation of the capacity of the B-cell for transmitter exocytosis, because it was observed that tetraethylammonium (TEA)-induced inhibition of the delayed voltagedependent $\mathrm{K}^{+}$current induced both spike broadening and synaptic facilitation regardless of training history. Collectively, these results demonstrate that training-induced facilitation at $\mathrm{B}$-cell synapses is attributable to the effects of a reduction of a presynaptic $\mathrm{K}^{+}$conductance on action potential kinetics and suggest another critical similarity between the cellular basis for learning in Hermissenda and other invertebrate systems.

Key words: synaptic facilitation; spike broadening; $K^{+}$channels; associative learning; exocytosis; Hermissenda synaptic IPSPs in the A photoreceptor that are generated in response to action potentials evoked in the B-cell (Frysztak and Crow, 1994; Schuman and Clark, 1994). Although these two forms of learning-related neuronal facilitation may arise independently, they share at least some mechanistic similarities. Most notably, each requires the training-related stimulation of protein kinase C (PKC; Farley and Auerbach, 1986; Alkon et al., 1988; Matzel et al., 1990; Schuman and Clark, 1994; Talk et al., 1996, 1997; Frysztak and Crow, 1997; for review, see Matzel et al., 1998).

The conjoint reliance of both enhanced excitability and synaptic facilitation on PKC raises the question of whether these two effects of conditioning share a common underlying mechanism. The changes in the general excitability of B photoreceptors after conditioning are believed to reflect a persistent reduction of voltage- and $\mathrm{Ca}^{2+}$-dependent $\mathrm{K}^{+}$currents $\left(I_{\mathrm{A}}\right.$ and $I_{\mathrm{K}-\mathrm{Ca}}$, respectively; Crow and Alkon, 1980; West et al., 1982; Alkon et al., 1982, 1985; Farley and Alkon, 1982, 1987; Collin et al., 1988; Farley, 1988). It is possible that this biophysical modification of the B-cell somatic membrane might in itself underlie (or contribute) to synaptic facilitation, because any reduction of $\mathrm{K}^{+}$efflux 
during an action potential is likely to slow the rate of membrane repolarization, and consequently, to enhance $\mathrm{Ca}^{2+}$-dependent release of transmitter from the B-cell. This possibility has not been subjected to empirical tests, but the application of Hodgkin and Huxley simulations to the B-cell of Hermissenda suggests that a decrease in conductance through $I_{\mathrm{A}}$ will in fact result in the prolongation of evoked action potentials (Fost and Clark, 1996).

Although the possibility that associative training of Hermissenda induces the broadening of action potentials in the B-cell has not been explored, there is precedent for such a mechanism at the synapse between the siphon sensory neurons and efferent motor neurons that mediate the gill withdrawal reflex in Aplysia. Simply stated, the temporal convergence of a conditioned stimulus (CS; e.g., touch-induced depolarization of the siphon sensory neurons) with an unconditioned stimulus (US; e.g., noxious stimulation of presynaptic tail sensory neurons) induces action potential broadening in the siphon sensory neurons that in turn facilitates transmitter release and the consequent EPSP amplitude recorded in the postsynaptic motor neurons that mediate gill withdrawal (Castellucci and Kandel, 1976; Hawkins et al., 1983; Hochner et al., 1986; Baxter and Byrne, 1989, 1990; Sugita et al., 1992, 1997; Goldsmith and Abrams, 1992; Clark et al., 1994). Thus this form of presynaptic facilitation of transmitter release is believed to account in part for the generation of CS-induced conditioned responses (enhanced gill withdrawal) after associative conditioning of Aplysia (for review, see Byrne and Kandel, 1996).

The experiments reported here were intended to test the possibility that training-induced facilitation of somatic excitability and synaptic transmission in the Hermissenda B-cell are mediated by a common biophysical mechanism. Moreover, elucidation of the mechanism underlying synaptic facilitation in Hermissenda will provide a basis for comparison with the training-induced synaptic facilitation observed in Aplysia and might aid in the identification of conserved principles of associative learning and cellular plasticity (for initial attempts at such synthesis, see Clark and Schuman, 1992; Matzel et al., 1998).

In our first experiment, we will ascertain whether in vitro associative conditioning of Hermissenda produces spike broadening or other modifications [e.g., in the afterhyperpolarization (AHP) or peak amplitude] of action potential waveforms in the B photoreceptor. In a second experiment, we assess whether an increase in action potential width is associated with synaptic facilitation between the B and A photoreceptors, and likewise, whether mechanisms independent of the modulation of the presynaptic spike waveform (e.g., enhanced mobilization of transmitter or increased sensitivity of postsynaptic receptors) also contribute to synaptic facilitation. Next, we directly test whether a specific reduction in $\mathrm{K}^{+}$conductance through $I_{\mathrm{A}}$ class channels in the B-cell (as accompanies behavioral conditioning) produces an increase in spike width in B photoreceptors and enhancement of concomitant IPSPs recorded from A photoreceptors. In a final experiment, the ability of paired training to occlude the action of 4-aminopyridine (4-AP) will be tested. Collectively, these experiments will provide a systematic test of the hypothesis that a reduction of $I_{\mathrm{A}}$ and its associated spike broadening is sufficient to account for synaptic enhancement at connections of Hermissenda type B photoreceptors after associative conditioning.

\section{MATERIALS AND METHODS}

Subjects. Adult Hermissenda crassicornis were obtained from Sea Life Co. (Sand City CA) and stored in a light- and temperature-controlled aquarium containing recirculating, refrigerated $\left(12^{\circ} \mathrm{C}\right)$ artificial seawater. A 12 hr light/dark cycle was maintained under dim levels of light passed through yellow acetate. Experimental manipulations were conducted during the middle $8 \mathrm{hr}$ of the light phase. Animals were fed portions of finely ground TetraMarine Flakes on alternating days.

Electrophysiology. The pedal and cerebroplural ganglia (the "nervous system") of Hermissenda, including the eyes and statocysts, were surgically isolated and prepared for electrophysiological analysis by securing it with insect pins to strips of silicone grease on a glass slide. To facilitate electrode placement, the nervous systems were incubated at $24^{\circ} \mathrm{C}$ for $7-9$ $\mathrm{min}$ in a solution of $1 \mathrm{mg} / \mathrm{ml}$ protease (P-6141; Sigma, St. Louis, MO) dissolved in artificial seawater (ASW: $430 \mathrm{~mm} \mathrm{NaCl}, 10 \mathrm{~mm} \mathrm{CaCl}_{2}, 50$ $\mathrm{mm} \mathrm{MgCl} 2,10 \mathrm{~mm} \mathrm{KCl}$, buffered with Tris to $\mathrm{pH}$ 7.4). In the subsequent recording session, the nervous system was routinely perfused with $18^{\circ} \mathrm{C}$ ASW. Intracellular recordings in the $\mathrm{A}$ and $\mathrm{B}$ photoreceptors were obtained with 25-60 M $\Omega$ glass electrodes (3.0 M KAc fill in ASW) attached to an Axoclamp 2A amplifier (Axon Instruments, Burlingame, CA) using a balanced bridge circuit. In all experiments, the following criterion were used to determine the viability of a cell for inclusion in an experiment. Type B and A-cells were accepted if after dark adaptation they maintained resting potentials at or below -45 and $-55 \mathrm{mV}$, respectively, exhibited little spontaneous activity in the dark (B-cells $<0.5 \mathrm{~Hz}$; A-cells $<0.2 \mathrm{~Hz}$ ), and displayed normal charging curves and lightinduced generator potentials of at least $25 \mathrm{mV}$. When hair cell-induced IPSPs in the B-cell were generated, a compound IPSP in response to mechanical hair cell stimulation of at least $-3 \mathrm{mV}$ was considered acceptable. In practice, most cells $(>90 \%)$ for which a stable impalement is maintained meet these criterion.

In vitro associative training. In various experiments, two types of in vitro training were used to approximate the conditions that prevail during exposure of the intact animal to associative conditioning with light (photoreceptor stimulation; CS) and rotation (presynaptic hair cell stimulation; US). These two procedures are designated "procedure I" and "procedure II."

In procedure I, a B photoreceptor (either a medial or intermediate B-cell) was impaled with a 25-40 $\mathrm{M} \Omega$ microelectrode filled with $3.0 \mathrm{M}$ KAc. After 6 min of dark adaptation (from an imposed resting potential of $-60 \mathrm{mV}$, maintained by a -0.1 to $-0.6 \mathrm{nA}$ constant current injection), each preparation was exposed to paired or unpaired presentations of light and mechanical statocyst stimulation (vestibular organ comprising 13 hair cells). For this stimulation, a polished glass probe extending from a piezoelectric crystal (Archer 273-073) was connected to the output of an audio oscillator (Hewlett-Packard $200 \mathrm{AB}$, operated at $1600 \mathrm{~Hz}$ during oscillation), and the tip of this probe was rested on the statocyst. Activation of the probe (by audio oscillation) produced a circular movement of the stataconia inside the cyst (estimated at several hundred revolutions per minute) and resulted in a depolarization of the hair cells and transmitter release onto the postsynaptic photoreceptors of the eye. For paired (associative) training, five CS-US (light-hair cell stimulation) pairings were presented at $120 \mathrm{sec}$ intertrial intervals. On each paired trial, a $5 \mathrm{sec}$ light co-terminated with $4 \mathrm{sec}$ of hair cell stimulation. Explicitly unpaired presentations of light and hair cell stimulation (a control for nonassociative exposure to stimuli) were presented in a similar manner but with a $60 \mathrm{sec}$ interval between the light and rotation.

Pre- and post-training measures to evaluate the effect of training on the excitability and the action potential kinetics of the B-cell were acquired before the first CS presentation and again 6 min after the final training event. All measures were taken from an imposed resting potential of -60 $\mathrm{mV}$ (via $-0.1-0.6 \mathrm{nA}$ constant current injection). Input resistance of the $\mathrm{B}$-cell membrane was determined by recording the voltage response of the B-cell to $-0.4 \mathrm{nA}$ of injected current, and the changes in elicited spikes were assessed in response to $+0.6 \mathrm{nA}$ current injections. Single action potentials were recorded in response to an injected current ramp (typically $0.1-0.3 \mathrm{nA}$ applied over $5-10 \mathrm{sec}$ ) sufficient to elicit a single spike, i.e., an action potential that was temporally isolated from another spike by at least $2 \mathrm{sec}$ (preventing any influence of spike discharge frequency on the kinetics of the action potential). The mean value of two action potentials elicited by this method at each time point (for each cell) was used for summary statistics and analyses. The spike amplitude and the AHP were measured relative to the prespike membrane potential. Action potential width was measured from a fixed fraction of the spike at a point corresponding to $35 \%$ of its maximal amplitude.

Pilot work indicated that it was not feasible to use the previous in vitro training method (procedure I) during recordings of the synaptic interaction between the B and A photoreceptor because of the high likelihood that at least one electrode impalement would be lost during repetitive 
mechanical stimulation of the statocyst. Consequently, a different in vitro training procedure (procedure II) was used in which the synaptic interaction between the B and A photoreceptor was assessed only after conditioning. For procedure II, surgically isolated nervous systems (with an intact visual-vestibular network) were prepared for electrophysiological analysis as described above. Each nervous system was then placed in an ASW (supplemented with $40 \mathrm{~mm}$ glucose)-filled Petri dish in a darkened incubator $\left(14^{\circ} \mathrm{C}\right)$ for $6 \mathrm{~min}$, after which the nervous system was exposed to 12 presentations of a $5 \mathrm{sec}$ light (CS) and $4 \mathrm{sec}$ rotation (US) that either co-terminated (paired) or were separated by a $60 \mathrm{sec}$ interval (unpaired). In the case of paired training, each trial was separated by a $120 \mathrm{sec}$ intertrial interval. The CS was a $40 \mathrm{~W}$ (nominal, at $130 \mathrm{~V}$ ) light mounted $60 \mathrm{~cm}$ above the nervous system that produced illumination of $50 \mathrm{fcd}$ on the nervous system. The US was produced by a Lab Line shaker (model 4600), which when operated produced an orbital rotation of 300 $\mathrm{rpm}$, with $4 \mathrm{~mm}$ of total displacement. These conditioning parameters have previously been found to produce excitability changes in the $\mathrm{B}$ photoreceptor that are comparable with those observed after the in vitro procedure from the previous experiment (Matzel et al., 1990; Muzzio et al., 1997). Two minutes after the final stimulus presentation, each nervous system was placed in a dark container (an opaque Petri dish) and transferred to an electrophysiology stage where an A and B photoreceptor (combinations of a medial or intermediate B-cell and either a medial or lateral A-cell) were impaled with a $40-60 \mathrm{M} \Omega(3.0 \mathrm{M} \mathrm{KAc}$ fill) microelectrode. After an additional 5 min of dark adaptation $(\sim 10 \mathrm{~min}$ after training), a single B-cell action potential was elicited during an injected current ramp initiated from an imposed resting membrane potential sufficient to completely eliminate spontaneous activity in the B-cell (i.e., -65 to $-75 \mathrm{mV}$ ) to limit any synaptic depression. The concomitant A-cell IPSP (recorded from an imposed membrane potential of $-60 \mathrm{mV}$ ) was recorded for analysis offline, and the mean value of five such IPSPs (15-20 sec intervals) from each nervous system was used for statistical analysis. In addition, B-cell input resistance and evoked spike rate was assessed as in the previous experiment.

Effect of 4-AP on B-cell membrane currents. Outward membrane currents on the B-cell soma were recorded under a single electrode voltage clamp before and after application of the A-type $\mathrm{K}^{+}$channel blocker 4-AP. A type B photoreceptor was impaled with a single $10-13 \mathrm{M} \Omega$ microelectrode filled with $3.0 \mathrm{M} \mathrm{KCl}$. Electrode capacitance was minimized by maintaining a shallow depth of the extracellular bath, by isolating the recording stage from ground, and by mounting the microelectrode directly to the head stage preamplifier. The amplifier was operated in discontinuous single-electrode voltage-clamp mode, and sampling rates ranged from 10 to $15 \mathrm{kHz}$. A voltage output display was monitored continuously to ensure that the voltage drop across the electrode induced by current pulses had dissipated between voltage samples, thus ensuring that the measured voltage accurately reflected the membrane potential of the cell. Outward currents were elicited with $300-\mathrm{msec}$ depolarizing command steps from holding potentials of -70 and -40 $\mathrm{mV}$. A family of currents was obtained in response to depolarizing command steps applied in $10 \mathrm{mV}$ increments from the holding potential $+10 \mathrm{mV}$. Leak currents were assessed in response to equivalent hyperpolarizing command steps. Currents were recorded in ASW containing 0 or $0.25 \mathrm{~mm} \mathrm{4-AP}$ and $0 \mathrm{Na}^{+}$(to synaptically isolate the photoreceptor and to eliminate voltage-dependent $\mathrm{Na}^{+}$currents; osmolarity was maintained by the equivalent addition of tetramethylammonium chloride to the solution). To evaluate the effect of 4-AP on the fast, transient $I_{\mathrm{A}}$, a holding potential of $-70 \mathrm{mV}$ was used. To evaluate the slower outward $\mathrm{K}^{+}$currents in isolation, $I_{\mathrm{A}}$ was inactivated by using a holding potential of $-40 \mathrm{mV}$. Capacitance transients in the current records settled in $<2$ msec, and voltage steps occurred with a rise time (to $95 \%$ of peak) of $<0.5 \mathrm{msec}$. Holding currents of less than $-3.0 \mathrm{nA}$ to maintain a membrane potential of $-70 \mathrm{mV}$ were required if a cell was to be accepted for analysis. Data were acquired and analyzed digitally using a Digidata 1200 interface and Axon Instruments Axoscope software (version 7.1).

Effect of 4-AP on B photoreceptor synaptic efficacy. Pairs of A and B photoreceptors (combinations of a medial or intermediate B-cell and either a medial or lateral A-cell) with reliable synaptic interactions were recorded from after a 6 min dark adaptation period using the paired recording procedure described above. In normal ASW, spikes were elicited in the B-cell, and IPSPs were recorded in the A-cell. After these baseline measures, 4-AP $(0.25$ or $0.5 \mathrm{~mm})$ was added to the bath, and IPSPs were again recorded within 3-5 min. The mean values of four IPSPs recorded before and after 4-AP application were recorded in each cell.
Occlusion of 4-AP effects by previous paired training. The capacity of 4-AP (an A-type $\mathrm{K}^{+}$channel antagonist) and TEA (an antagonist of the delayed rectifier $\mathrm{K}^{+}$channel) to induce spike broadening and synaptic facilitation in the B-cell was assessed after paired or unpaired in vitro conditioning. The preparation of the nervous system and the in vitro conditioning procedure was as described above for procedure II. After a 5 min dark adaptation period, nervous systems were exposed to 12 presentations of a $5 \mathrm{sec}$ light (CS) and $4 \mathrm{sec}$ rotation (US) that either co-terminated (paired) or were separated by a $60 \mathrm{sec}$ interval (unpaired). After training, an A- and a B-cell were impaled in each nervous system, the preparation was allowed an additional $5 \mathrm{~min}$ of dark adaptation, and B-cell voltage responses and action potentials were recorded $(\sim 10 \mathrm{~min}$ after training). In addition, the IPSP in the A-cell in response to the B-cell spike was recorded. For each nervous system, these recordings were first made in normal ASW. Subsequently, the same measures were obtained 3-5 min after addition to the bath of 4-AP $(0.25 \mathrm{~mm})$ and again after the application of TEA $(10 \mathrm{~mm})$.

\section{RESULTS}

\section{Paired training broadens type B photoreceptor action potentials}

Although observations of synaptic facilitation between Hermissenda type B and A photoreceptors have been reported (Frysztak and Crow, 1994; Schuman and Clark, 1994), the origin of this type of synaptic facilitation had been unknown. A recent computational model of the $\mathrm{B}$ photoreceptor had predicted that the reduction of $I_{\mathrm{A}}$ that accompanies associative conditioning in Hermissenda could contribute to synaptic facilitation by increasing the duration of the presynaptic action potential (Fost and Clark, 1996). An increase in spike width has been shown to influence synaptic transmission in many preparations by promoting the quantal release of neurotransmitter and enhancing postsynaptic potentials (Klein and Kandel, 1980; Llinas, 1991; Sabatini and Regher, 1997) (for review, see Byrne and Kandel, 1996).

In the present experiment, we find in Hermissenda that paired in vitro conditioning (procedure I) significantly broadens type $\mathrm{B}$ photoreceptor action potentials in addition to producing a general increase in membrane excitability. After paired training $(n=$ 8 ), input resistance increased $(>40 \%$, measured from voltage deflections in response to $-0.4 \mathrm{nA}$ current injection) for at least 6 min (the final measure), whereas in cells exposed to unpaired light and vestibular stimulation $(n=8)$, input resistance tended to decrease (indicative of normal rundown) relative to baseline (Fig. 1A). A two-way repeated measures ANOVA confirmed a significant difference between groups $\left[F_{(1,14)}=19.59 ; p<0.001\right]$. Baseline (pre-training) measures were equivalent across the two groups $\left[t_{(14)}=-0.307 ; p=0.764\right]$ : paired, $42.8 \pm 6.26 \mathrm{mV}$; unpaired, $40.6 \pm 3.42 \mathrm{mV}$ (mean $\pm \mathrm{SEM}$ ). Post hoc analysis using the Student-Newman-Keuls test revealed individual group differences indicating that the paired group was significantly different from the unpaired group at both time points $(2$ and 6 min after training) but found no significant differences within groups at the two post-training time points.

In addition, paired training produced an increase in the evoked spike rate in response to $+0.6 \mathrm{nA}$ current pulses $(400 \mathrm{msec})$ at both 2 and 6 min after training, whereas there was a slight reduction in the evoked spike rate in cells from the unpaired group at both time points (Fig. 1B). The difference between groups was confirmed by a two-way repeated measures ANOVA $\left[F_{(1,14)}=14.608 ; p<0.005\right]$. Baseline (pre-training) measures were equivalent across the two groups $\left[t_{(14)}=2.08 ; p=0.056\right]$ : paired, $4.25 \pm 0.37$ spikes; unpaired, $5.75 \pm 0.62$ spikes. Post hoc analysis with the Student-Newman-Keuls test further indicated group differences such that the paired group was significantly 
A

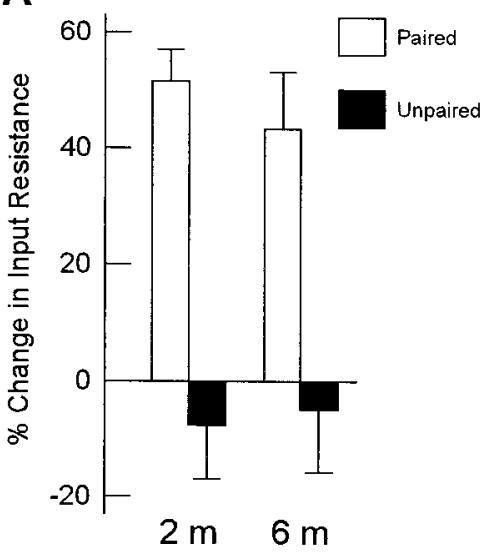

B

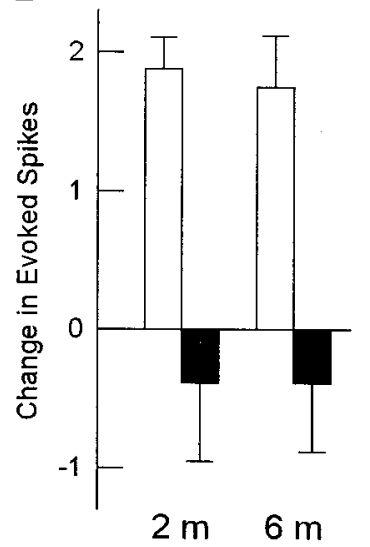

Figure 1. A, Mean change in input resistance [as measured by the change in voltage response elicited by $-0.4 \mathrm{nA}(400 \mathrm{msec})$ current injection] at both 2 and $6 \mathrm{~min}$ after training plotted as percentage of pre-training values (baseline pre-training values: paired, $40.6 \pm 3.42 \mathrm{mV}$; unpaired, $42.8 \pm 6.26)$. Data are shown for paired $(n=8)$ and unpaired $(n=8)$ groups. Input resistance increased after in vitro paired training but not after unpaired presentations of a $5 \mathrm{sec}$ light and $4 \mathrm{sec}$ vestibular stimulation (procedure I). Error bars indicate SE. $B$, Change in number of evoked action potentials from pre-training measure in response to +0.6 nA $(400 \mathrm{msec})$ current injection 2 and $6 \mathrm{~min}$ after training (baseline pre-training values: paired, $4.25 \pm 0.37$; unpaired, $5.75 \pm 0.62$ ). Evoked spike rate increased after paired training but not when the stimuli were presented in an unpaired manner.

different from the unpaired group at both time points, whereas within each group there were no differences across the two post-training time points. In Figure $1 C$ sample voltage records of typical responses to -0.4 and $+0.6 \mathrm{nA}(400 \mathrm{msec})$ are presented.

The increase in excitability of the B photoreceptor soma membrane after paired training was paralleled by an increase in the action potential duration. Unpaired (nonassociative) training was accompanied by only small, nonsignificant changes in spike width (Fig. 2A; for representative traces, see Fig. $3 A$ ). Results from a two-way repeated measures ANOVA revealed significant group differences $\left[F_{(1,14)}=28.031 ; p<0.0005\right]$, along with a significant effect of time $\left[F_{(1,14)}=8.31 ; p<0.05\right]$. Baseline (pre-training) measures in both groups were equivalent $\left[t_{(14)}=0.781 ; p=\right.$ 0.448]: paired, $13.8 \pm 0.05 \mathrm{msec}$; unpaired, $12.9 \pm 0.1 \mathrm{msec}$. Post hoc analysis using the Student-Newman-Keuls test identified individual group differences such that the paired group was different from the unpaired group at both post-training time points. The observation that the action potential in the B-cell is prolonged after associative conditioning suggests that broadening of the action potential in type B photoreceptors may contribute, at least in part, to synaptic facilitation in conditioned Hermissenda.

Because of electrotonic decay and the heterogeneous distribution of ion channels, the action potentials that we have recorded at the soma membrane provide only an approximation of the resultant voltage response in the synaptic terminals. However, because of the relatively higher resistance of the soma and short distance $(<120 \mathrm{um})$ of the recording site from the terminal branches, differences between action potentials recorded at these two sites are small and are limited to a decline in the amplitude (but not a slowing of the rising and falling phases) of the action potential as it propagates down the axon (Alkon, 1974; for similar results in Aplysia sensory cells, see Belardetti et al., 1986; Ham-
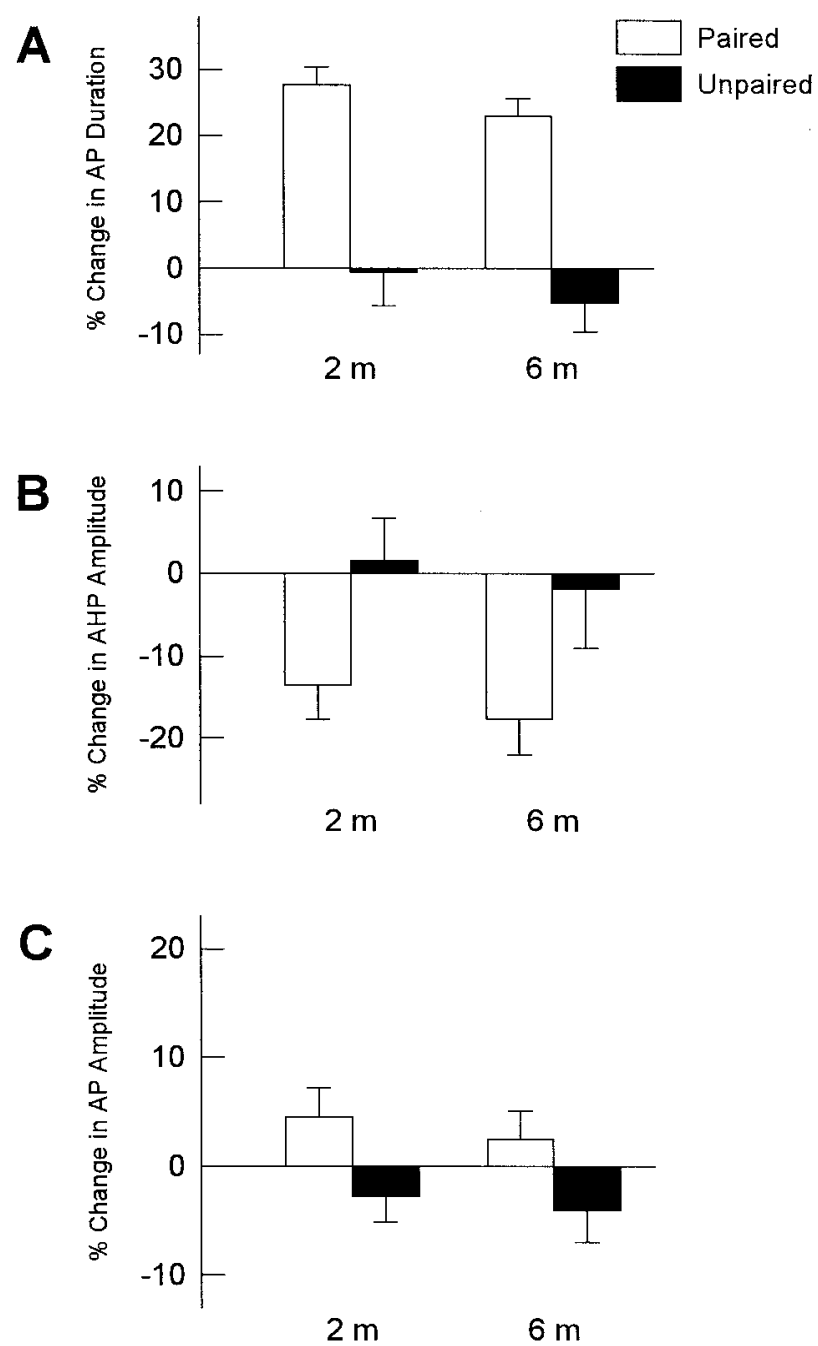

Figure 2. A, Mean percent change from pre-training baseline in action potential $(A P)$ duration in the B-cell recorded 2 and 6 min after training. Spike duration substantially increased after paired $(n=8)$ but not unpaired training $(n=8)$ when assessed at both post-training time points. $B$, The AHP was reduced after paired but not unpaired training at both 2 and $6 \mathrm{~min}$ after training. $C$, Spike amplitude was not statistically different from baseline after either treatment at either time after training. Error bars indicate SE.

mer et al., 1989). Thus the training-induced modifications of action potential kinetics that we observe at the soma can be reasonably expected to reflect comparable modifications at the terminal branches. This conclusion is supported by data described below in which we observe a direct correspondence between the duration of the action potential recorded in the B-cell soma and the synaptic potentials recorded in the postsynaptic A-cell.

\section{Paired training produces a reduction of the AHP in B photoreceptor action potentials}

Membrane afterhyperpolarization after the generation of a single action potential arises from a transient increase in $\mathrm{K}^{+}$conductance in most vertebrate and invertebrate neurons. Typically in mammalian neurons, an initial fast AHP current (lasting 1-2 $\mathrm{msec}$ ) is followed by a slow AHP current (50-1000 msec) that is mediated by Apamin-sensitive $\mathrm{K}^{+}$channels that are gated by an elevation in intracellular $\mathrm{Ca}^{2+}$ (Hille, 1992). In Hermissenda, associative conditioning produces a specific reduction of the 
A
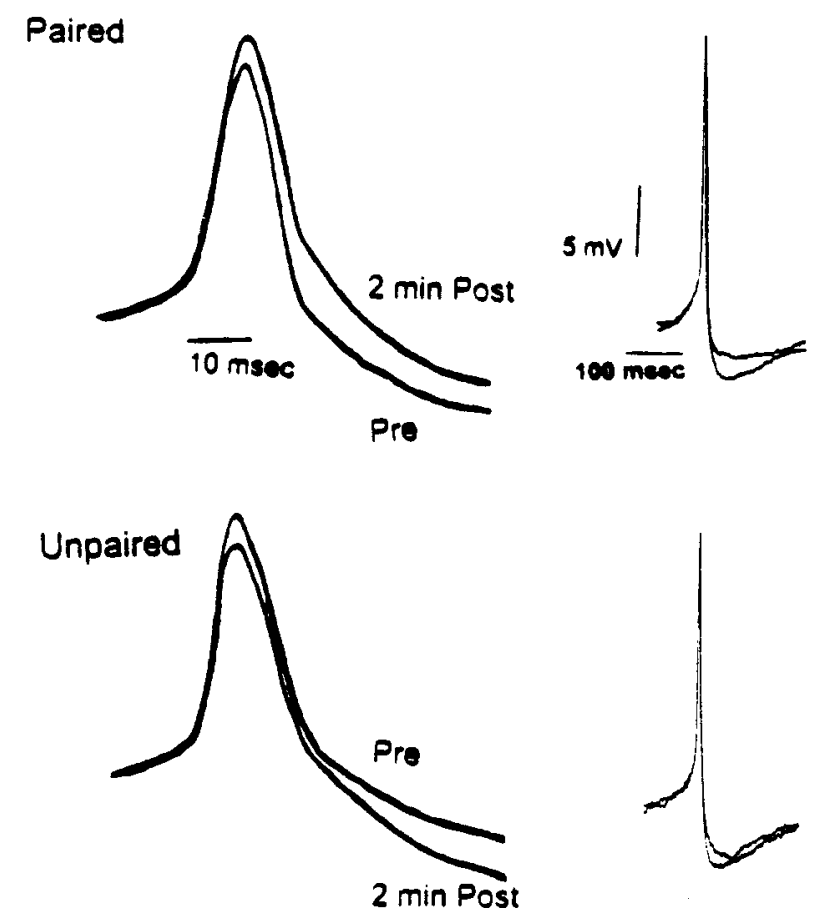

Figure 3. Form of the action potential in the B-cell (provided at two different time scales) before and 2 min after either paired (top, $A, B$ ) or unpaired (bottom, $A, B$ ) training. Paired training produces alterations in the kinetics of the action potential, including spike broadening (best illustrated in $A$ ) and a reduction of the AHP (best illustrated in $B$ ), whereas there are no significant changes in the action potential waveform after unpaired training.

$\mathrm{Ca}^{2+}$-dependent $\mathrm{K}^{+}$current $\left(I_{\mathrm{K}-\mathrm{Ca}}\right)$, which contributes to the increase in membrane resistance and enhanced excitability of $\mathrm{B}$ photoreceptors (Alkon et al., 1985). In the B photoreceptor, this current has been characterized based on its sensitivity to voltagedependant $\mathrm{Ca}^{2+}$ influx, modulation by baclofen and serotonin, and its contribution to spike repolarization and generation of the AHP (Alkon et al., 1982, 1985; Matzel et al., 1995; Yamoah and Crow, 1995).

After paired training we observed a significant reduction in the AHP of B-cell action potentials relative to baseline. Conversely, there was a slight, nonsignificant increase in the AHP in the cells from the unpaired group 2 min after training and a slight reduction 6 min after training (Fig. $2 B$; for representative traces, see Fig. $3 B$ ). A two-way repeated measures ANOVA found significant group differences $\left[F_{(1,14)}=5.36 ; p=0.036\right]$. Baseline (pretraining) measures were equivalent across the two groups $\left[t_{(14)}=\right.$ $-1.83 ; p=0.088]$ : paired, $7.21 \pm 0.66 \mathrm{mV}$; unpaired, $5.68 \pm 0.52$ $\mathrm{mV}$. Post hoc analysis using the Student-Newman-Keuls test indicated that paired training resulted in a reduction of the AHP compared with the unpaired group at both 2 and 6 min after training. The AHP reduction in both groups at 6 compared with 2 min may be a function of the temporal kinetics of the dissipation of the rise in intracellular $\mathrm{Ca}^{2+}$ concentration after the final light response (Muzzio et al., 1998). This reduction in the AHP after paired training presumably contributes to the increase in spike discharge rate during depolarizing stimuli (e.g., light), as well as to other measures of increases in cellular excitability (Connor and Stevens, 1971; Fost and Clark, 1996).

\section{Training does not alter spike amplitude in B photoreceptor action potentials}

The effect of training on action potential amplitude was also examined. After paired training there was a small (nonsignificant) increase in spike amplitude at 2 and 6 min after training, whereas unpaired training resulted in a nonsignificant decrease in spike amplitude at both time points (Fig. $2 C$; for representative traces, see Fig. 3A,B). A two-way repeated measures ANOVA did not find a significant difference between groups $\left[F_{(1,14)}=3.667\right.$; NS], an effect of time $\left[F_{(1,14)}=2.622 ;\right.$ NS $]$ or interaction $\left[F_{(1,14)}=\right.$ 0.126 ; NS]. Baseline (pre-training) measures were equivalent across the two groups $\left[t_{(14)}=-0.46 ; p=0.653\right]$ : paired, $11.64 \pm$ 1.15; unpaired, $11.08 \pm 0.41$. This result suggests that the changes in spike duration and AHP amplitude were not reliably accompanied by alterations in the amplitude of the spike.

\section{Synaptic facilitation occurs without a change in the initial slope of A photoreceptor spike-elicited IPSPs}

Despite evidence for spike broadening in the B photoreceptor, the possibility remains that a parallel mechanism is operating at the synapse or at the postsynaptic cell to affect synaptic facilitation after paired training. In Aplysia, only part of the synaptic facilitation after conditioning is dependent on spike broadening, with a second mechanism believed to directly influence transmitter mobilization (Dale and Kandel, 1990; Byrne and Kandel, 1996). This type of spike duration-independent (SDI) process affecting transmitter release and/or alterations in postsynaptic receptor sensitivity has been implicated in a number of other model systems, including enhancement at the crayfish neuromuscular junction, at the granule cell $\rightarrow$ purkinje cell synapse in the cerebellum, and in forms of hippocampal plasticity (Delaney et al., 1991; Chavez-Noriega and Stevens, 1994; Weisskopf et al., 1994; Trudeau et al., 1996; Chen and Regher, 1997; Sabatini and Regher, 1997; Goy and Kravitz, 1989). It is possible to differentiate between a spike width-dependent mechanism and a process that effects the neurosecretory machinery or postsynaptic receptor sensitivity based on an analysis of the initial slope of the postsynaptic response after paired training (both mechanisms should influence the amplitude of the postsynaptic response, whereas only the latter should effect the slope). If spike broadening (because of a reduction of $\mathrm{K}^{+}$conductance) were the sole basis for synaptic facilitation after associative training, it would follow that $\mathrm{Ca}^{2+}$ influx during the rising phase of an action potential would not have been effected by training, because the reduced rate of repolarization during the falling phase of the action potential would increase the amplitude and duration of the $\mathrm{Ca}^{2+}$ signal but would have no effect on its initial influx during the rising phase of the spike. Thus it is commonly held that spike broadening (and other influences on the peak or duration of the presynaptic $\mathrm{Ca}^{2+}$ signal) should not alter the initial slope of a postsynaptic potential but, rather, should induce an increase in the amplitude and duration of the postsynaptic response. In contrast, if an increase in the slope of a postsynaptic potential is observed after training, it could be inferred that $\mathrm{Ca}^{2+}$ influx is accelerated during the rising phase of the spike, that neurotransmitter release in response to a constant $\mathrm{Ca}^{2+}$ signal has been facilitated, or that an increase in the sensitivity of postsynaptic receptors has occurred. A number of studies have demonstrated an effect of associative training on the slope of the postsynaptic 
A

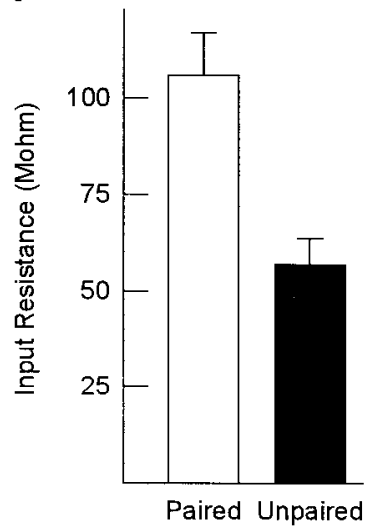

B

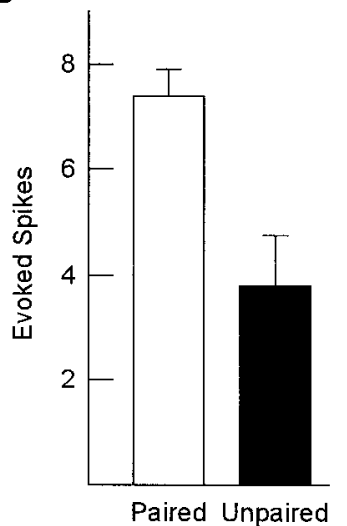

Figure 4. $A$, Mean B-cell input resistance 10 min after training plotted for paired $(n=5)$ and unpaired $(n=5)$ cells. Input resistance increased after paired in vitro training but not after unpaired presentations of a $5 \mathrm{sec}$ light and $4 \mathrm{sec}$ orbital rotation. $B$, Evoked action potentials in response to $+0.6 \mathrm{nA}(400 \mathrm{msec})$ current injection after training. Spike rate increased after paired training but not when the stimuli were presented in an unpaired manner.

response in Aplysia, adding to the evidence that dual mechanisms of facilitation are involved in this system (Hochner et al., 1986; Dale et al., 1988; Braha et al., 1990; Sacktor and Schwarz, 1990; Goldsmith and Abrams, 1991; Ghirardi et al., 1992; Klein, 1993, 1994; Clark et al., 1994; Eliot et al., 1994; Bao et al., 1998).

To determine whether synaptic facilitation of connections between type B and type A photoreceptors is accompanied by a change in the initial slope of the postsynaptic IPSP, a second set of nervous systems were trained using an in vitro conditioning procedure (procedure II). Overall, the results demonstrated that paired training produced increases in excitability of the B photoreceptor soma membrane and synaptic enhancement of the IPSP recorded in the A photoreceptor but did not alter the initial slope of the postsynaptic response relative to the IPSP in cells from untrained preparations.

After paired training $(n=5)$ the membrane input resistance was doubled, compared with the unpaired group $(n=5)$. A $t$ test confirmed a significant group difference $\left[t_{(8)}=3.80 ; p<0.01\right]$ (Fig. 4A). In addition, the number of evoked spikes to a $+0.6 \mathrm{nA}$ current pulse was also significantly greater in the paired group versus the unpaired group $\left[t_{(8)}=-3.29 ; p<0.05\right]$ (Fig. $4 B$ ).

Analysis of the IPSP recorded in the A photoreceptor further revealed that paired training produced synaptic facilitation of the postsynaptic response relative to unpaired training, but that the slope of the IPSP did not differ between the two training conditions. The IPSP was more than doubled after paired training (4 $\mathrm{mV}$ ) relative to unpaired training $(1.74 \mathrm{mV}$; see Fig. $5 A)$, and this difference between groups was confirmed by a $t$ test $\left[t_{(8)}=-5.71\right.$; $p<0.0005]$. There was no significant difference between groups in the measure of the initial slope of the A photoreceptor IPSP (Fig. $5 B)\left[t_{(8)}=0.158 ; p=0.879\right]$. In Figure $5 C$ sample voltage records of typical evoked $\mathrm{B}$ photoreceptor action potentials and a concomitant postsynaptic IPSP recorded in the A photoreceptor for both the paired and unpaired group are presented. These results suggest the possibility that in Hermissenda, synaptic facilitation may arise entirely in response to changes in the presynaptic action potential waveform in the $\mathrm{B}$ photoreceptor.

A

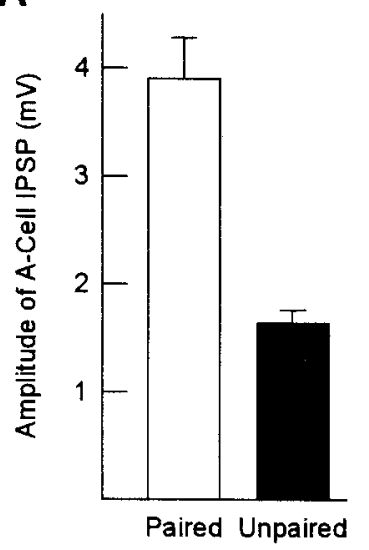

C
B

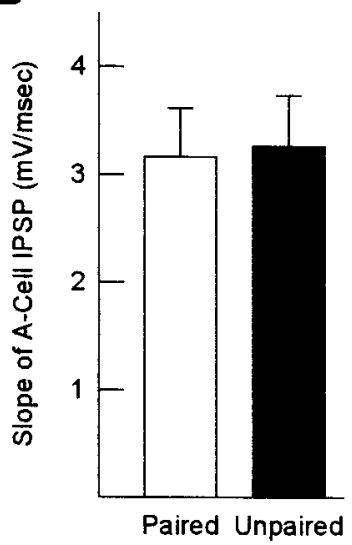

Paired

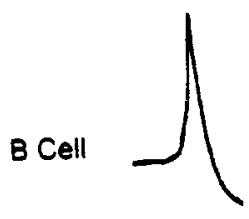

A Celi

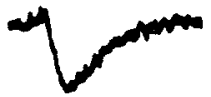

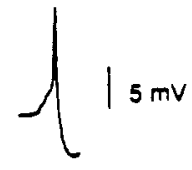

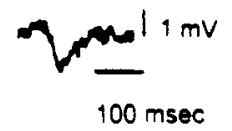

Figure 5. $A$, Paired training $(n=5)$ produces synaptic facilitation of connections between type B and type A photoreceptors compared with unpaired training $(n=5)$. This enhancement of unitary B photoreceptor spike-elicited IPSPs recorded from A photoreceptors is seen as an increase in the amplitude of the postsynaptic response $(B)$ but with no change in the initial slope of the IPSP. Mean values were obtained $10 \mathrm{~min}$ after training. Error bars indicate SE. $C$, Representative examples of B photoreceptor action potentials and the concomitant spike-elicited IPSPs recorded from A photoreceptors after either paired or unpaired training.

\section{Modulating the A-current with 4-AP broadens action potentials and produces synaptic facilitation without altering the initial slope of A photoreceptor spike- elicited IPSPs}

Although conditioning in Hermissenda is accompanied by a reduction in the B photoreceptor of at least two classes of outward $\mathrm{K}^{+}$currents $\left(I_{\mathrm{A}}\right.$ and $I_{\mathrm{K}-\mathrm{Ca}}$; Alkon et al., 1985; Farley, 1988), it is unknown how these currents effect the kinetics of the action potential in these cells and thus whether a reduction of either or both of these currents (and/or other outward currents (AcostaUrquidi and Crow, 1993) is sufficient to modulate synaptic transmission from the B to A photoreceptors. Because of physiological data describing the kinetics of $I_{\mathrm{A}}$ (which exhibits strong inactivation at membrane potentials more positive than resting potential), it is not clear that the reduction of this current could contribute 

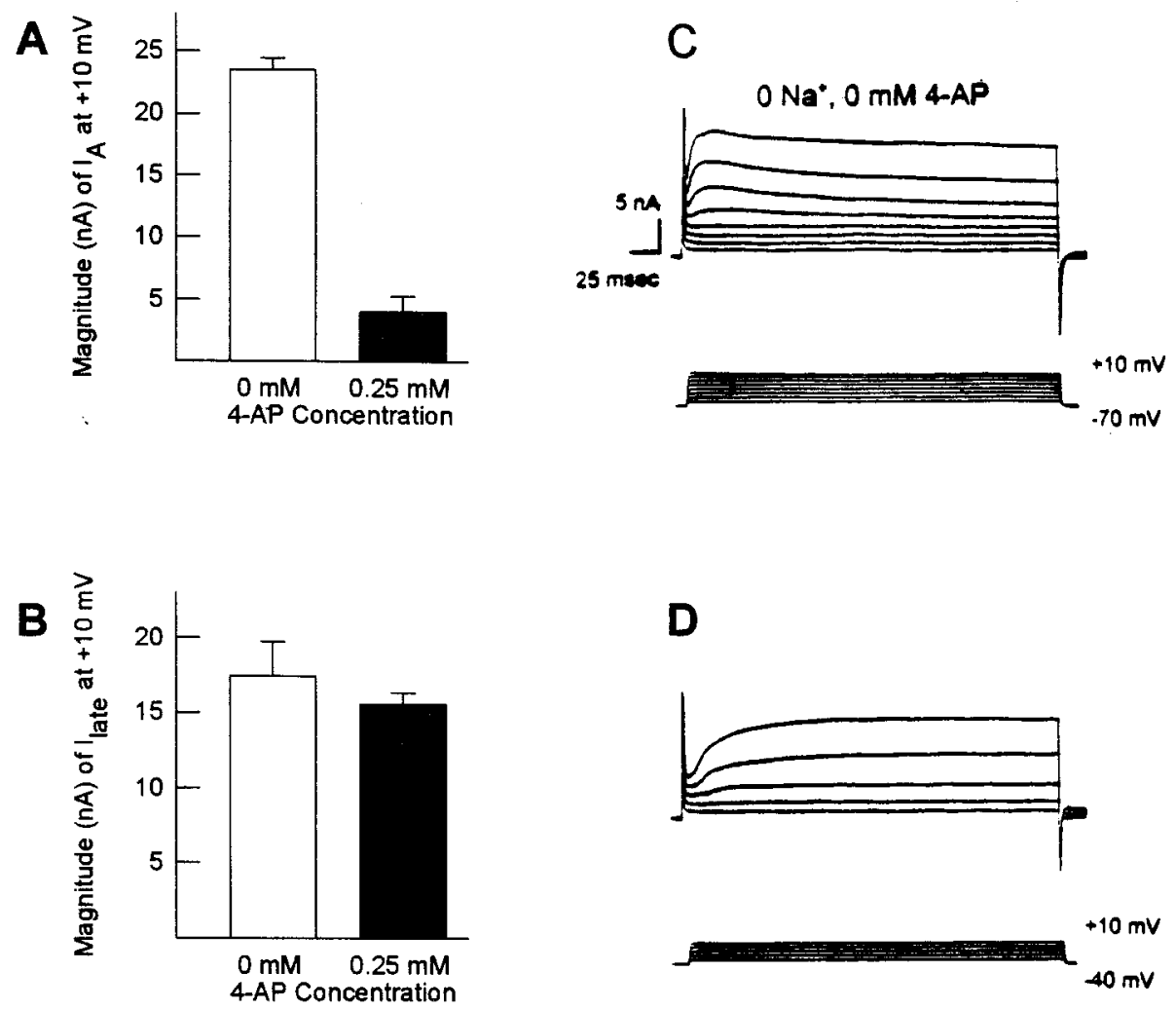

D

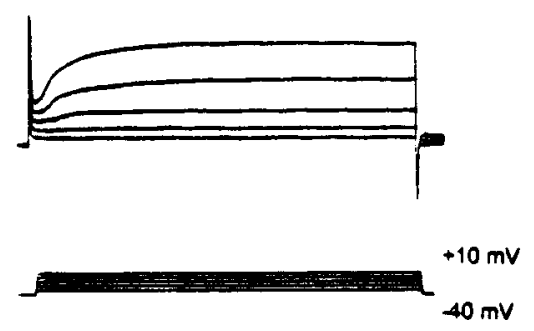

O Na: $0.25 \mathrm{mM} 4-\mathrm{AP}$

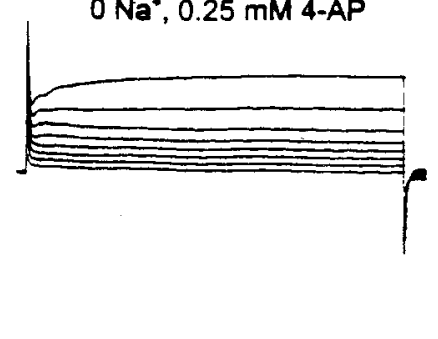

Figure 6. Mean values of currents before and after 4-AP exposure $(A, B)$. A, Mean magnitude (nanoamperes) of outward currents at $+10 \mathrm{mV}$ stepped for $300 \mathrm{msec}$ from a holding potential of $-70 \mathrm{mV}(n=4)$. $B$, Mean values of the late currents from the same cells when stepped to $+10 \mathrm{mV}$ from a holding potential of $-40 \mathrm{mV}(n=4)$. Bath application of $0.25 \mathrm{~mm}$ 4-AP reduced the early transient outward potassium current $\left(I_{\mathrm{A}}\right)$ but had little effect on the composite late current $\left(I_{\text {late }}\right.$, consisting primarily of $I_{\mathrm{K}-\mathrm{V}}$ and $\left.I_{\mathrm{K}-\mathrm{Ca}}\right)$. The top group of records is the total outward current, with voltage responses provided in the bottom records. The total outward currents (the early transient $I_{\mathrm{A}}$ and the composite late currents) were assessed by stepping the membrane potential in intervals of $10 \mathrm{mV}$ from -70 to $+10 \mathrm{mV}(C)$. The left group of currents were obtained before 4-AP application, and the right records were obtained after 4-AP. Note that the early current $\left(I_{\mathrm{A}}\right)$ was markedly reduced after 4-AP application. The same cells used in $A$ were also stepped to $+10 \mathrm{mV}$ from a holding potential of $-40 \mathrm{mV}$ in $10 \mathrm{mV}$ intervals ( $D$; where $I_{\mathrm{A}}$ undergoes near-complete inactivation), thereby isolating the late outward currents $\left(I_{\text {late }}\right.$, consisting primarily of the residual noninactivating tail of $I_{\mathrm{A}}$ as well as $I_{\mathrm{K}-\mathrm{V}}$ and $\left.I_{\mathrm{K}-\mathrm{Ca}}\right)$. The left records were obtained before 4-AP application, and the right records were obtained after 4-AP application. Note only a small reduction in the late currents as a consequence of 4-AP exposure, a reduction that likely reflects the elimination of the tail portion of $I_{\mathrm{A}}$.

to either spike broadening or synaptic facilitation (AcostaUrquidi and Crow, 1993; Frysztak and Crow, 1994). However, a computational model of $\mathrm{B}$ photoreceptor membrane currents indicates that a reduction in $I_{\mathrm{A}}$ would directly induce spike broadening and would in turn facilitate transmitter release (Fost and Clark, 1996).

The fast transient outward $\mathrm{K}^{+}$current $\left(I_{\mathrm{A}}\right)$ was modulated using a $0.25 \mathrm{~mm}$ concentration of 4-AP. After application of 4-AP, single-electrode voltage-clamp recordings from the B-cell indicated that $I_{\mathrm{A}}$ was reduced $83 \%$ relative to its baseline amplitude [as recorded with voltage steps from $-70 \mathrm{mV}$ to $+10 \mathrm{mV}, n=4$; $\left.t_{(6)}=12.0 ; p<0.0001\right]$. Representative current records and membrane voltage steps are presented in Figure $6 C$, and summary data $(n=4)$ are presented in Figure $6 A$. Despite its strong inhibition of $I_{\mathrm{A}}$, this concentration of 4-AP had no effect on the late composite outward current (composed of a small noninactivating portion of $I_{\mathrm{A}}$ and/or an unidentified outward current, as well as $I_{\mathrm{K}-\mathrm{V}}$ and $I_{\mathrm{K}-\mathrm{Ca}}$ ). The late composite current was measured in isolation by applying a prepulse voltage command to $-40 \mathrm{mV}$ (where $I_{\mathrm{A}}$ is inactivated) and subsequently stepping the membrane potential to $+10 \mathrm{mV}$. Under these conditions, the late current $($ at $+10 \mathrm{mV}$ ) was reduced $10 \%$ in the presence of $4-\mathrm{AP}$, but this effect did not reach significance $\left[t_{(6)}=0.745 ; p=0.485\right]$.
Representative records of the late outward current and membrane voltage steps are presented in Figure $6 D$, and summary data are presented in Figure $6 B$. Based on previous observations, it is likely that the small nonsignificant effect of $0.25 \mathrm{~mm} 4-\mathrm{AP}$ on the late currents represents a reduction of the noninactivating tail portion of the A current or another unidentified outward current (Matzel et al., 1995). In total, these results indicate a relatively selective inhibition by 4 -AP of the $I_{\mathrm{A}}$ class $\mathrm{K}^{+}$current.

During current-clamp recordings of synaptically coupled type $\mathrm{B}$ and A photoreceptors $(n=4), 4-\mathrm{AP}$ altered the spike waveform in the B photoreceptor and enhanced evoked IPSPs recorded in the A photoreceptor but did not alter the initial slope of the postsynaptic response. At the $0.25 \mathrm{~mm}$ concentration, 4-AP broadened the B photoreceptor action potential by $26 \%$ but had no significant effect on the AHP (-2\%) or spike amplitude (1\%). At a $0.5 \mathrm{~mm}$ concentration, 4-AP broadened action potentials by $29 \%$ and still had no significant affect on the AHP $(-0.5 \%)$ or spike amplitude $(12 \%)$ (Fig. $7 A-C)$. A one-way repeated measures ANOVA confirmed the effect of 4-AP ( 0 mM baseline, 0.25 $\mathrm{mM}$, and $0.5 \mathrm{mM})$ on action potential duration $\left[F_{(2,5)}=141.7 ; p<\right.$ $0.000001]$, and post hoc analysis using the Student-NewmanKeuls test demonstrated significant differences between the baseline condition ( $0 \mathrm{~mm} 4-\mathrm{AP})$ and both concentrations of 4-AP but 

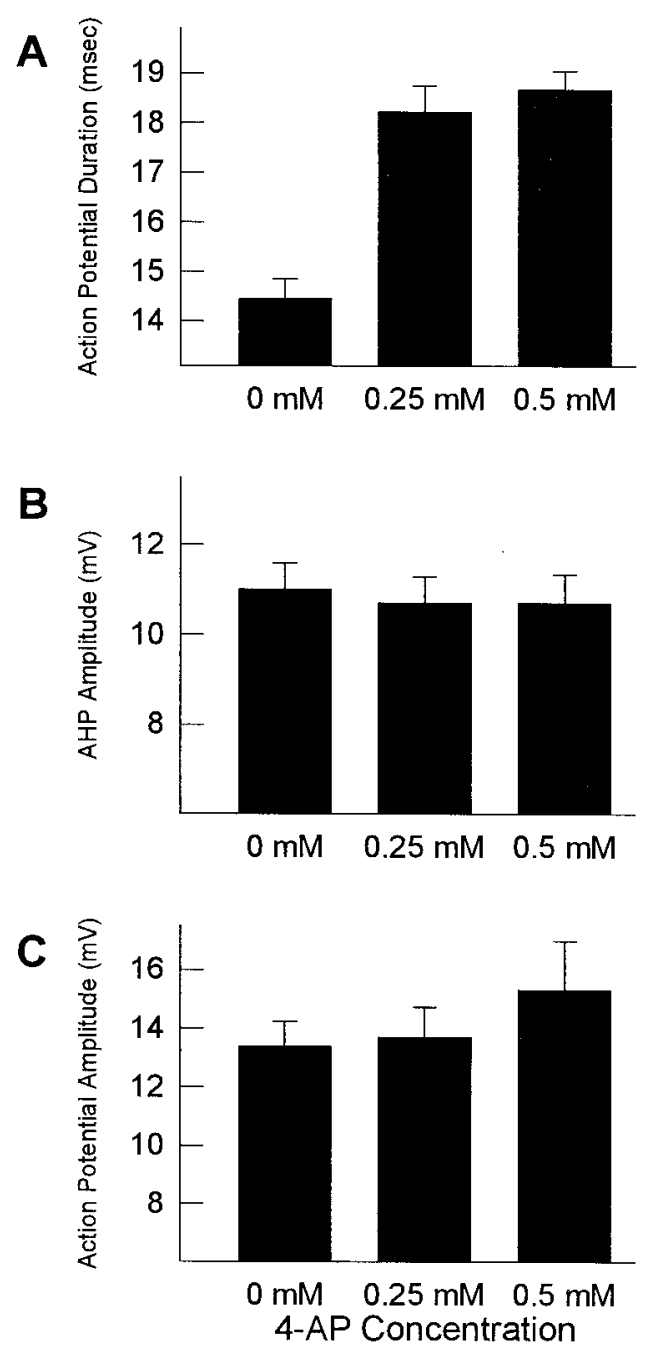

Figure 7. A, Action potential duration recorded in $0,0.25$, and $0.5 \mathrm{~mm}$ 4-AP. Spike width substantially increased after $0.25 \mathrm{~mm} 4$-AP, and no further significant increase was observed in response to $0.5 \mathrm{~mm} 4-\mathrm{AP}$. The percent increase in action potential width in response to 4-AP was comparable with that observed after paired presentations of light and vestibular stimulation. $B$, The AHP was not significantly altered by either concentration of 4-AP. $C$, Spike amplitude was not significantly effected by either concentration of 4-AP.

no difference between 0.25 and $0.5 \mathrm{~mm}$ 4-AP. For the AHP, a one-way repeated measures ANOVA found no significant group differences $\left[F_{(2,5)}=0.568 ; p=0.599\right]$. A one-way repeated measures ANOVA performed on measures of spike amplitude suggested a trend toward a significant effect of 4-AP $\left[F_{(2,5)}=5.754\right.$; $p=0.051$ ], but this effect was clearly limited to the higher concentration $(0.5 \mathrm{~mm})$ of the drug. This latter observation is important, because at the lower concentration $(0.25 \mathrm{~mm})$ of 4-AP (which had no affect on spike amplitude), significant facilitation of synaptic strength was still observed (see below), and the higher concentration produced no further increase in this level of facilitation. This indicates that spike broadening by 4-AP is sufficient to account for the maximum possible degree of synaptic facilitation.

Modulating the presynaptic waveform with 4-AP produced facilitation of the postsynaptic IPSP evoked in the A-cell, nearly doubling it from its baseline value at both the $0.25 \mathrm{~mm}(2.5-4.8$ $\mathrm{mV})$ and $0.5 \mathrm{~mm}(2.5-4.3 \mathrm{mV})$ concentrations, as summarized in
Figure $8 A$. This effect was confirmed by a one-way repeated measures ANOVA $\left[F_{(2,5)}=29.775 ; p<0.005\right]$ and with post hoc analysis using the Student-Newman-Keuls test demonstrating differences between baseline premeasures and both the 0.25 and $0.5 \mathrm{~mm} 4$-AP conditions but no difference between either 4-AP concentration. This change in the amplitude of the postsynaptic response was not accompanied by a shift in the initial slope of the IPSP (Fig. $8 B$ ), and this observation was confirmed by a one-way repeated measures ANOVA $\left[F_{(2,5)}=1.903 ; p=0.243\right]$. Figure $8 C$ contains representative voltage records of typical evoked B photoreceptor action potentials and a concomitant postsynaptic IPSP recorded in the A photoreceptor in normal ASW (0 mM 4-AP) or after bath application of 0.25 or $0.5 \mathrm{~mm} 4-\mathrm{AP}$.

\section{Paired training occludes the effects of 4-AP on the B-cell action potential and A-cell IPSP}

In a final experiment, we assessed whether paired associative training (procedure II) occluded the effect of $0.25 \mathrm{~mm} 4$-AP application on B photoreceptor action potentials and the associated A photoreceptor IPSP. An occlusion of the effect of 4-AP by previous paired training would indicate that the influence of 4-AP on the B-cell spike and the amplitude of the A-cell IPSP is mechanistically similar to that induced by paired training and does not reflect a direct pharmacological influence of 4-AP on the neurotransmitter exocytosis mechanism or on the input resistance of the postsynaptic A-cell. In addition, occlusion of 4-AP effects by paired but not unpaired training would significantly strengthen our conclusion that a reduction of $I_{\mathrm{A}}$-type $\mathrm{K}^{+}$channels underlies training-induced synaptic facilitation.

Again, paired training $(n=5)$ produced a significant increase in the membrane resistance relative to unpaired training $(n=5)$ $\left[t_{(8)}=-2.94 ; p<0.05\right]$, as summarized in Figure $9 \mathrm{~A}$. In addition, the number of evoked spikes in response to $+0.6 \mathrm{nA}$ current pulses was significantly greater in B-cells after paired relative to unpaired training $\left[t_{(8)}=-4.22 ; p<0.001\right]$, as summarized in Figure $9 B$.

In addition, in this experiment we replicated the results from the first experiment in this series, demonstrating that paired associative conditioning broadened the action potential recorded in the B-cell relative to unpaired training (Fig. 10 $A$ ) and, moreover, was associated with an increase in the amplitude of the IPSP recorded in the A-cell (Fig. 10B). After these initial post-training measures, 4-AP $(0.25 \mathrm{~mm})$ was added to the extracellular bath. The effect of 4-AP on the B-cell spike and the IPSP in the A-cell varied as a function of previous training. After paired training, 4-AP produced no further broadening of the evoked action potential in the B photoreceptor and had no affect on the amplitude of the IPSP recorded in the A photoreceptor. After unpaired training, 4-AP induced both a broadening of the action potential in the B-cell and an increase in the amplitude of the IPSP in the A-cell. Representative voltage records obtained under all conditions are provided in Figure $10 C$.

A two-way repeated measures ANOVA demonstrated a significant group (paired vs unpaired) difference $\left[F_{(1,8)}=6.34 ; p<\right.$ 0.05 ], a significant effect of 4-AP [ASW vs $0.25 \mathrm{~mm} 4-\mathrm{AP} ; F_{(1,8)}=$ 17.05; $p<0.005]$, and a significant interaction of 4-AP with previous training $\left[F_{(1,8)}=6.44 ; p<0.05\right]$. In addition, post hoc analysis using the Student-Newman-Keuls test demonstrated individual group differences. Application of 4-AP had no effect on the width of action potentials in the B-cells after paired training but did significantly increase the duration of B-cell spikes after unpaired training (Fig. 10A). Also, although post-training 
A

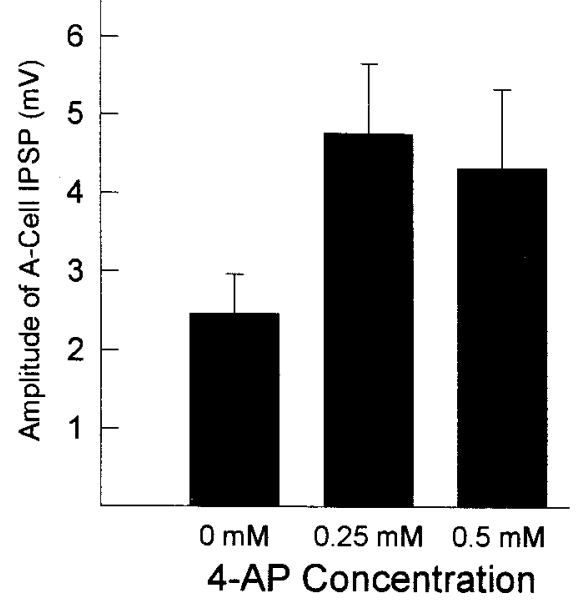

B

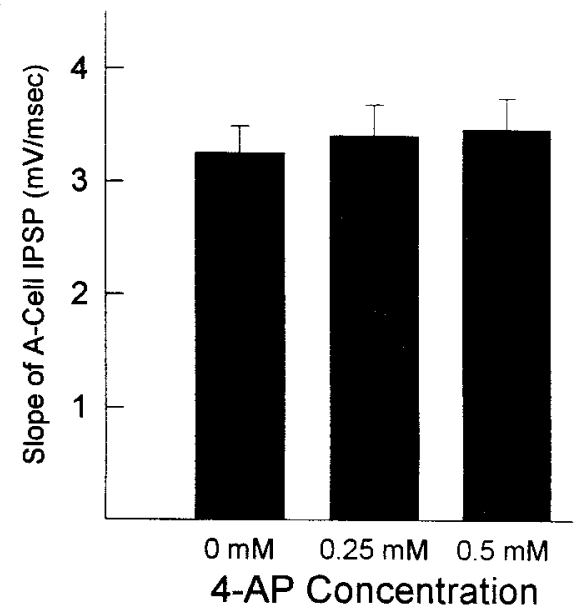

Figure 8. $A$, 4-AP $(0,0.25,0.5 \mathrm{~mm})$ application produces synaptic facilitation of connections between type B and type A photoreceptors compared with baseline measures (mean value of postsynaptic responses recorded in each of four pairs of cells). This enhancement of B photoreceptor spikeelicited IPSPs recorded from A photoreceptors is observed in the amplitude of the postsynaptic response $(B)$ but not in the initial slope of the IPSP. These results are qualitatively and quantitatively comparable with the effect of paired training on synaptic efficacy at connections of B to A photoreceptors. $C$, Representative examples of $\mathrm{B}$ photoreceptor spike-elicited IPSPs recorded in A photoreceptors in $0,0.25$, and $0.5 \mathrm{~mm}$ 4-AP.
A

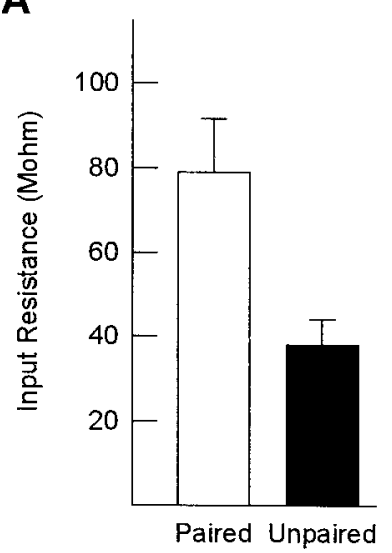

B

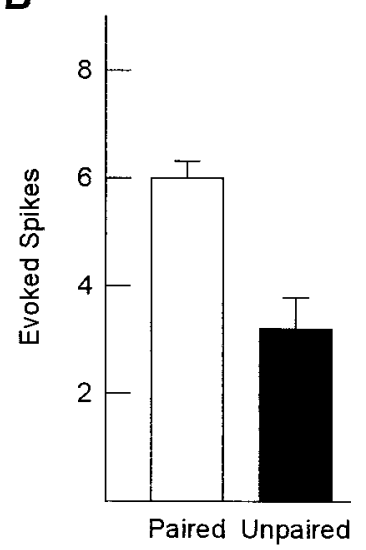

Figure 9. $A$, Mean B-cell input resistance $10 \mathrm{~min}$ after training plotted for paired $(n=5)$ and unpaired $(n=5)$ cells. Input resistance increased after in vitro paired training but not after unpaired presentations of a $5 \mathrm{sec}$ light and 4 sec orbital rotation (procedure II). $B$, Evoked action potentials in response to $+0.6 \mathrm{nA}(400 \mathrm{msec})$ current injection after training. Spike rate increased after paired training but not when the stimuli were presented in an unpaired manner.

measures taken in ASW indicated that spikes in B-cells after paired training were broader relative to unpaired training, after 4-AP application spike width in the unpaired group was statistically equivalent to the paired group.

Comparisons of the A-cell IPSP paralleled the data for spike width in that the amplitude of the A photoreceptor IPSP was greater in the paired group compared with the unpaired group when measured in ASW after conditioning. This observation was confirmed by a two-way repeated measures ANOVA that revealed a difference between groups $\left[F_{(1,6)}=11.4 ; p=0.015\right]$, a difference based on drug treatment [ASW vs $0.25 \mathrm{~mm} 4-\mathrm{AP} ; F_{(1,6)}$ $=22.5 ; p=0.003$ ], and a significant interaction of 4-AP with the type of training $\left[F_{(1,6)}=20.2 ; p=0.004\right]$. Post hoc comparisons using the Student-Newman-Keuls test demonstrated the following individual group differences. For the paired group $(n=4)$, 4-AP was ineffective in enhancing the IPSP, but in the unpaired group $(n=4)$, 4-AP application produced synaptic facilitation, increasing the IPSP from the level observed in ASW. In addition, the mean IPSP (which was greater in the paired group compared with the unpaired group when measured in ASW) was statistically equivalent in both groups when measured after perfusion of 4-AP, indicative of the selective enhancement by 4-AP of the IPSP in the unpaired condition.

In a subset of nervous systems from each group (paired, $n=3$; unpaired, $n=2$ ), the measurements in 4-AP were followed by the addition of $10 \mathrm{~mm}$ TEA to the extracellular bath. (Because of technical limitations, this manipulation could only be completed in this smaller subsample of the cells.) This final manipulation was intended to establish whether the lack of an effect of 4-AP on the synaptic response after paired training was attributable to saturation of the transmitter exocytotic machinery. In the B-cell, TEA blocks the delayed rectifier potassium current $\left(I_{\mathrm{K}-\mathrm{V}}\right)$, but has relatively little effect on the A current (Matzel et al., 1996). After TEA application, the width of single spikes was increased in B-cells from both the paired $(27 \%)$ and unpaired nervous systems $(22 \%)$. Unlike 4-AP, TEA induced a comparable increase in the mean amplitude of the IPSP in A-cells from both the paired 


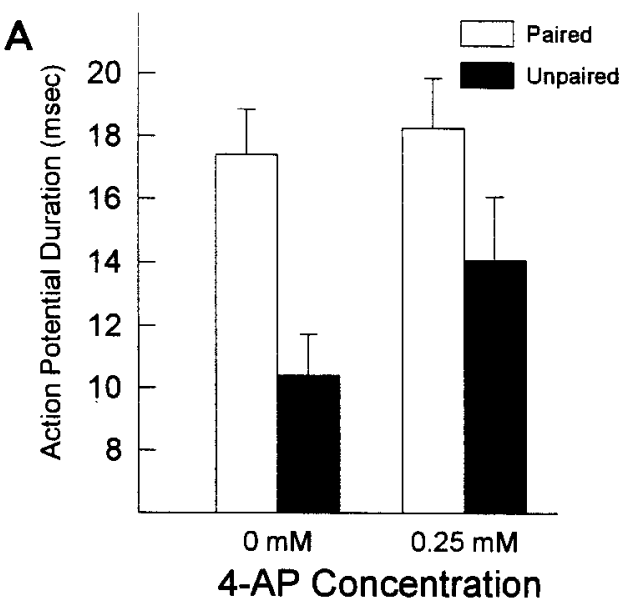

C

\section{Paired}

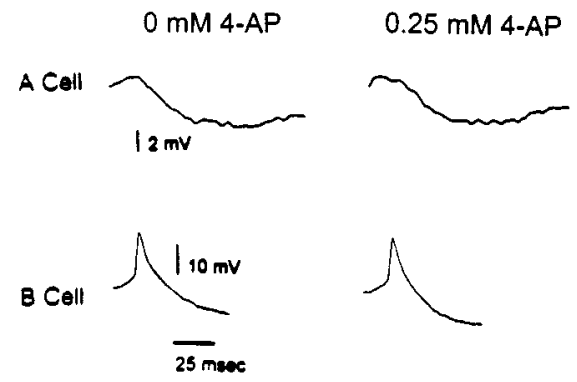

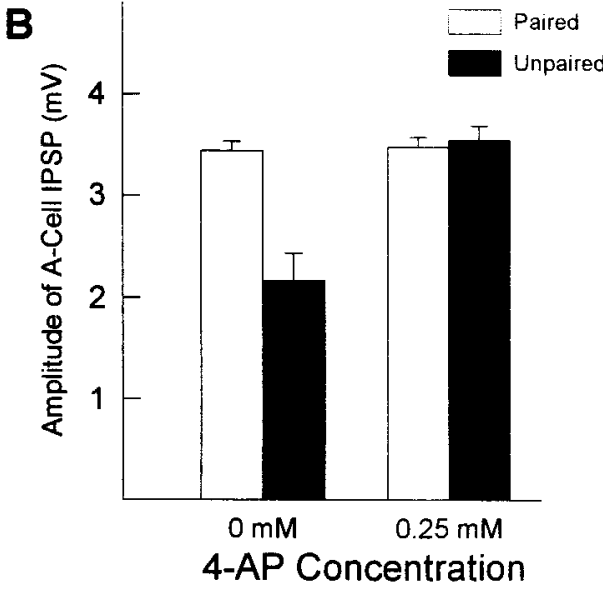

Unpaired

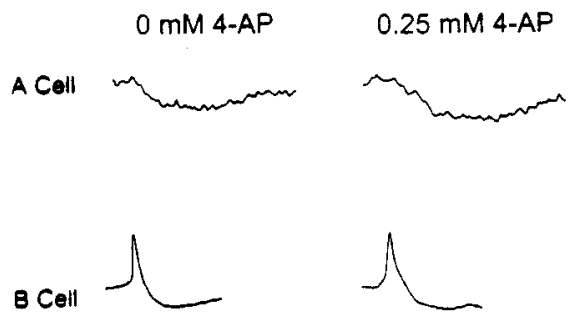

Figure 10. A, Action potential duration recorded in 0 (ASW) and 0.25 mM 4-AP after either paired $(n=5)$ or unpaired training $(n=5)$. Action potential broadening was observed after paired relative to unpaired training when recorded in $0 \mathrm{~mm}$ 4-AP (ASW). Spike width substantially increased after bath application of 0.25 mM 4-AP in the unpaired group, but the effect of 4-AP was occluded in the paired group with no further increase in spike width in response to application of $0.25 \mathrm{~mm} 4-\mathrm{AP}$. $B$, In addition, analysis of IPSPs in the A-cell elicited by single B photoreceptor action potentials revealed parallel results. Paired training increased the amplitude of A photoreceptor IPSPs compared with unpaired training $(n=4)$ when recorded in $0 \mathrm{~mm}$ 4-AP (ASW). Application of $0.25 \mathrm{~mm}$ 4-AP facilitated the postsynaptic response in the unpaired group but was ineffective in altering the amplitude of the IPSP in the paired group. $C$, Representative examples of $\mathrm{B}$ photoreceptor action potentials and concomitant IPSPs recorded from the A photoreceptors in 0 (ASW) and $0.25 \mathrm{~mm} 4-\mathrm{AP}$ after both paired and unpaired training.
$(+40 \%)$ and unpaired $(+43 \%)$ conditions. Summary data for cells from which recordings were made in both 4-AP and TEA are provided in Table 1.

In total, the results of this experiment confirm our observation that a reduction in $I_{\mathrm{A}}$ (as accompanies behavioral conditioning) can specifically broaden $\mathrm{B}$ photoreceptor action potentials and consequently facilitate synaptic transmission from the B-cell onto the A-cell in Hermissenda. Moreover, these results demonstrate that the $23-28 \%$ increase in presynaptic spike width induced by paired associative conditioning results in a relatively larger (85$90 \%$ ) enhancement of postsynaptic IPSP amplitude. Because these effects of training were mimicked by 4-AP, and because previous training entirely occluded the effects of 4-AP, it appears likely that a training-induced reduction of the A-type $\mathrm{K}^{+}$current can account in entirety for the training-induced synaptic enhancement observed at connections of type B photoreceptors. This supports the conclusion that the locus for synaptic facilitation of connections between B and A photoreceptors after associative conditioning is presynaptic and can be explained in terms of a biophysical mechanism, which involves the altered kinetics of the B photoreceptor spike.

\section{DISCUSSION}

\section{Prolongation of the presynaptic spike by reduced $\mathrm{K}^{+}$ conductance accounts for synaptic facilitation}

The present results provide an initial mechanistic account of learning-related synaptic facilitation in Hermissenda and describe a form of activity-dependent presynaptic spike broadening and synaptic facilitation that is analogous to that which has been described in Aplysia (for review, see Byrne and Kandel, 1996). In vitro associative training with light and vestibular stimulation resulted in a sustained increase in the duration of action potentials in the Hermissenda B photoreceptor. This spike broadening was accompanied by a nearly twofold increase in the amplitude of the synaptic potential in the postsynaptic A-cell evoked by an action potential in the B-cell. In contrast, the slope of the postsynaptic potential was unaffected by paired training, suggesting that a spike duration-independent influence on neurotransmitter exocytosis or postsynaptic receptor sensitivity did not contribute to the enhancement of synaptic efficacy.

It has been previously reported that associative conditioning of Hermissenda results in a reduction of current flow through voltage-dependent A-type $\mathrm{K}^{+}$channels on the B-cell soma (Alkon et al., 1985; Collin et al., 1988). Here, 4-AP was used to block the A-type $\mathrm{K}^{+}$current, and a prolongation of the action potential in the B-cell was observed that mimicked that which followed associative training. The increase in spike duration was accompanied by a two-fold increase in the amplitude of the postsynaptic potential in the A-cell. This 4-AP-induced synaptic facilitation occurred in the absence of any measurable effect of 4-AP on the initial slope of the postsynaptic potential, suggesting that a reduction of membrane $\mathrm{K}^{+}$conductance and the consequent prolongation of the action potential did not alter the initial rate of $\mathrm{Ca}^{2+}$ influx or transmitter exocytosis, but instead influ- 


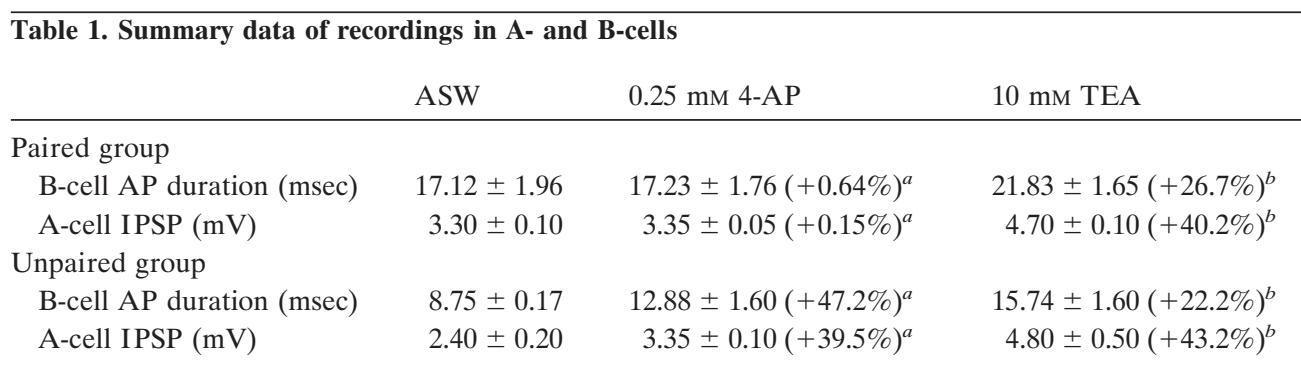

In vitro associative conditioning (procedure II) produces both action potential (AP) broadening in type B photoreceptors and synaptic facilitation of connections between type B and A photoreceptors in the paired group compared with unpaired training. Paired training occludes the effect of 4-AP, which blocks $I_{\mathrm{A}}$, on the width of the B-cell action potential and the amplitude of the evoked unitary IPSP recorded in the A-cell but does not inhibit the action of TEA, which blocks $I_{\mathrm{K}-\mathrm{V}}$, on the waveform of the B-cell action potential or the amplitude of the A cell IPSP. Alternatively, after unpaired training 4-AP is effective in broadening B-cell action potentials and augmenting synaptic efficacy at connections of B-to A-cells, and the application of TEA further increases the width of the B-cell spike and the amplitude of the A-cell IPSP. Data shown represent a subset from the occlusion experiment in which the additional effects of TEA were assessed (paired group, $n=$ 3; unpaired group, $n=2$ ). Data are presented as absolute values (mean $\pm \mathrm{SEM}$ ) with comparisons also given as percent change: ${ }^{a}$ relative to ASW; ${ }^{b}$ relative to 4-AP.

enced the magnitude and duration of $\mathrm{Ca}^{2+}$ influx and resultant transmitter release. The similar effects of 4-AP and paired training supports the likelihood that training-induced synaptic facilitation in Hermissenda arises from presynaptic alterations in the B-cell spike waveform.

Paired conditioning occluded the action of 4-AP on modulating spike duration and the synaptic potential, indicating that previous training had inhibited $I_{\mathrm{A}}$ in a manner analogous to the effects of 4-AP. Conversely, for cells that received unpaired presentations of light and rotation, 4-AP application mimicked the results of paired conditioning, suggesting that training-induced synaptic facilitation most probably arose as a consequence of a reduction of $I_{\mathrm{A}}$ and its influence on spike duration. Furthermore, the occlusion of 4-AP-induced synaptic facilitation by previous associative training demonstrates that the modulation of synaptic transmission by 4-AP is the consequence of its reduction of current flow through $I_{\mathrm{A}}$ channels and does not reflect a pharmacological affect of 4-AP on exocytosis or postsynaptic input resistance. In total, these results suggest that modulation of spike width in the B photoreceptor by a reduction in $I_{\mathrm{A}}$ can account for the synaptic enhancement at connections of B to A photoreceptors that we observed after associative training and that has been previously reported by others (Schuman and Clark, 1994; Frysztak and Crow, 1994).

At sensorimotor connections in Aplysia, serotonin application or associative training induces spike broadening and synaptic facilitation, attributable in part to the reduction of presynaptic current flow through $I_{\mathrm{K}-\mathrm{V}}$, a transient voltage-dependent $\mathrm{K}^{+}$ current (Baxter and Byrne, 1989, 1990; Goldsmith and Abrams, 1992; Hochner and Kandel, 1992; Sugita et al., 1994, 1997). Based on initial observations, it was believed that spike broadening could fully account for synaptic facilitation in this system (Klein et al., 1980; Kandel and Schwartz, 1982), but both mathematical modeling and empirical data have provided evidence for SDI influences on transmitter mobilization (Gingrich and Byrne, 1985, 1987; Hochner et al., 1986; Pieroni and Byrne 1992). In fact, synaptic facilitation and an increase in spontaneous vesicle release at sensorimotor synapses has now been observed in the absence of spike prolongation, both in response to 5-HT application or PKC activation by phorbol esters (Dale and Kandel, 1990; Ghirardi et al., 1992; Klein 1993, 1994; Eliot et al., 1994; Stark and Carew, 1999). These results suggest that SDI influences can contribute and in some instances account for training-induced synaptic facilitation. More recently, 4-AP was used to block $I_{\mathrm{K}-\mathrm{V}}$ in Aplysia sensory neurons, and this manipulation was compared with that of 5-HT application (Sugita et al., 1997). This experiment revealed that although SDI processes play an important role in the rapidly developing phase of 5-HT-induced synaptic facilitation, spike broadening may be more important for its later maintenance. These results of Sugita et al. (1997) are comparable with those reported here and suggest that Hermissenda B photoreceptors and Aplysia sensory neurons share a common mechanism for the expression of facilitation; i.e., that a persistent reduction of a transient voltage-dependent $\mathrm{K}^{+}$current increases action potential duration and consequently enhances synaptic transmission onto efferent targets.

Although the demonstration of activity-dependent modulation of spike duration and synaptic efficacy in Hermissenda photoreceptors is analogous to that observed in Aplysia sensory neurons (Hawkins et al., 1983; Hochner et al., 1986; Byrne, 1987; Baxter and Byrne, 1989, 1990; Goldsmith and Abrams, 1992; Sugita et al., 1992; Clark et al., 1994; Stark and Carew, 1999) (for review, see Byrne and Kandel, 1996), the biochemical determinants of this modulation are only partially analogous in the two systems (for review, see Matzel et al., 1998). Likewise, in the present report we find that synaptic enhancement in Hermissenda is not accompanied by a change in the initial slope of the postsynaptic response, as has been reliably reported in Aplysia (Hochner et al., 1986, Clark et al., 1994; Bao et al., 1998). This result suggests that synaptic facilitation in Hermissenda arises from a presynaptic biophysical mechanism and does not involve SDI effects on neurotransmitter exocytosis or postsynaptic receptor sensitivity as it may in Aplysia. Nevertheless, the conservation of the more basic mechanism of presynaptic facilitation across these two model systems suggests that these superficially disparate systems may be more similar than is commonly acknowledged (cf. Clark and Schuman, 1992; Matzel et al., 1998).

Spike broadening-dependent synaptic facilitation in Hermissenda (and, likewise, Aplysia) does appear to represent a distinct mechanism of memory storage compared with the role proposed for long-term potentiation (LTP) in the mammalian hippocampus, where synaptic potentiation has been postulated to arise from an enhanced release of glutamate and/or postsynaptic receptor sensitivity that occurs independently of presynaptic spike broadening (Laerum and Storm, 1994). Although the induction of LTP is accompanied by increases in postsynaptic cellular excit- 
ability (i.e., EPSP-spike potentiation; Bliss and Lomo, 1973), this increase may be unrelated to a reduction of membrane $\mathrm{K}^{+}$ conductance, at least as can be detected in recordings obtained from the cell soma (Bliss et al., 1987; Chavez-Noriega et al., 1990, Pugliese et al., 1994; Eichenbaum, 1996; Roberson et al., 1996; Albertson et al., 1997). However, it should be noted that the mechanism of LTP expression is not fully elucidated, with conflicting data denoting preynaptic (e.g., an increase in quantal release of glutamate) or postsynaptic (increases in receptor sensitivity or an activation of a silent receptor population) determinants (Bekkers and Stevens, 1990; Ambros-Ingerson et al., 1993; Isaac et al., 1995; Liao et al., 1995; Stevens and Sullivan, 1998). Moreover, although it does not play an obvious role in LTP, modulation of action potential kinetics can critically influence synaptic transmission in the vertebrate hippocampus and throughout the mammalian brain. For instance, activation of PKC (as typically accompanies LTP induction) or prolonged stimulation of metabotropic glutamate receptors each produce a marked broadening of action potentials in CA1 pyramidal neurons (Storm, 1987; Hu and Storm, 1991), suggesting a potential role for this mechanism in behaviorally relevant forms of synaptic modulation like those that have been hypothesized to induce LTP.

\section{Reduced afterhyperpolarization after paired associative conditioning}

In addition to spike broadening, paired in vitro training also induced a significant reduction of the AHP of single spikes in the B-cell. This decrease in AHP amplitude likely reflects a reduction of $\mathrm{K}^{+}$conductance through $I_{\mathrm{K}-\mathrm{Ca}}$, because previous work has indicated that in these cells the AHP is largely determined by an outward $\mathrm{K}^{+}$flux through the $I_{\mathrm{K}-\mathrm{Ca}}$ class channel (Matzel et al., 1995; Yamoah and Crow, 1995) and that this current is reduced after associative conditioning (Alkon et al., 1985; Farley, 1988). A training-induced decrease in AHP amplitude has previously been reported in Aplysia sensory neurons (Hawkins, 1981; Clark et al., 1994) and in CA1 hippocampal cells of rabbits after eye blink conditioning (Disterhoft et al., 1986, 1988; Coulter et al., 1989).

Although reduced by associative training, the B-cell AHP was not modulated by 4-AP, suggesting that modulation of $I_{\mathrm{A}}$ did not underlie the reduction of the AHP. Furthermore, 4-AP-induced spike broadening produced synaptic facilitation but had no effect on the AHP. This latter effect indicates that spike broadening in the absence of AHP reduction is sufficient to induce synaptic facilitation and that the modulation of the AHP plays yet a different role in the generation of conditioned responding in Hermissenda. For instance, a reduction of the AHP may play a role in the expression of increases in the excitability of the $\mathrm{B}$ photoreceptor after associative learning. In particular, a reduction of the AHP is likely to underlie the training-induced increased rate of spike discharge in response to a test light, as well as the prolonged depolarization after light offset. Also, evidence from other cell types indicates that $\mathrm{K}^{+}$flux through $\mathrm{Ca}^{2+}$ activated $\mathrm{K}^{+}$channels limits the duration of action potential and thus can influence synaptic transmission (Robitaille and Charlton, 1992). Were this the case in Hermissenda B-cells, then the reduction of $I_{\mathrm{K}-\mathrm{Ca}}$ may contribute to synaptic facilitation under some conditions, such as during prolonged periods of depolarization and repetitive firing, during which the A current may become inactivated.

\section{Conclusion}

In total, the results reported here indicate that paired associative conditioning in Hermissenda modulates the kinetics of the action potential in the B photoreceptor such that individual spikes are broadened and exhibit a reduced afterhyperpolarization, effects that are determined by reductions of current flow through $I_{\mathrm{A}}$ and $I_{\mathrm{K}-\mathrm{Ca}}$ classes of $\mathrm{K}^{+}$channels. The increase in spike duration was found to be a critical determinant of learning-related synaptic facilitation between B and A photoreceptors. This mechanism for synaptic enhancement shares features of presynaptic facilitation at Aplysia sensorimotor synapses and with alterations in both membrane currents and action potential waveform reported in hippocampal cells after classical conditioning of the rabbit's eye blink response (Disterhoft et al., 1986, 1988; Coulter et al., 1989).

\section{REFERENCES}

Acosta-Urquidi J, Crow T (1993) Differential modulation of voltagedependent currents in Hermissenda type B photoreceptors by serotonin. J Neurophysiol 70:541-547.

Albertson TE, Walby WF, Stark LG, Joy RM (1997) The effects of lindane and long-term potentiation (LTP) on pyramidal cell excitability in the rat hippocampal slice. Neurotoxicology 18:469-477.

Alkon DL (1974) Sensory interactions in the nudibranch mollusk Hermissenda crassicornis. Fed Proc 33:1083-1090.

Alkon DL, Lederhendler I, Shoukimas JJ (1982) Primary changes of membrane currents during retention of associative learning. Science 215:693-695.

Alkon DL, Sakakibara M, Forman R, Harrigan J, Lederhendler I, Farley J (1985) Reduction of two voltage-dependent $\mathrm{K}+$ currents mediates retention of a learned association. Behav Neural Biol 44:278-300.

Alkon DL, Naito S, Kubota M, Chen C, Bank B, Smallwood J, Gallant P, Rasmussen H (1988) Regulation of Hermissenda K+ channels by cytoplasmic and membrane-associated C-kinase. J Neurochem 51:903-917.

Ambros-Ingerson, Xiao P, Larson J, Lynch G (1993) Waveform analysis suggests that LTP alters the kinetics of synaptic receptor channels. Brain Res 620:237-244.

Bao JX, Kandel ER, Hawkins RD (1998) Involvement of presynaptic and postsynaptic mechanisms in a cellular analog of classical conditioning at Aplysia sensory-motor neuron synapses in isolated cell culture. J Neurosci 18:458-466.

Baxter DA, Byrne JH (1989) Serotonergic modulation of two potassium currents in the pleural sensory neurons of Aplysia. J Neurophysiol 62:665-679.

Baxter DA, Byrne JH (1990) Differential effects of cAMP and serotonin on membrane current, action potential duration, and excitability in somata of pleural sensory neurons of Aplysia. J Neurophysiol 64:978-990.

Bekkers JM, Stevens CF (1990) Presynaptic mechanism for long-term potentiation in the hippocampus. Nature 346:724-729.

Belardetti F, Schacher S, Kandel ER (1986) The growth cones of Aplysia sensory neurons. Modulation by serotonin of action potential duration and single potassium channel currents. Proc Natl Acad Sci USA 83:7094-7098.

Bliss TVP, Lomo T (1973) Long-lasting potentiation of synaptic transmission in the dentate area of the anaesthetized rabbit following stimulation of the perforant path. J Physiol (Lond) 232:331-356.

Bliss TVP, Chavez-Noriega LE, Halliwell JV (1987) Long-term potentiation is associated with an increase in the excitability of pyramidal cells in area CA1 of the rat hippocampal slice. J Physiol (Lond) 377:391-408.

Braha O, Dale N, Hochner B, Klein M, Abrams TW, Kandel ER (1990) Second messengers involved in the two processes of presynaptic facilitation that contribute to sensitization and dishabituation in Aplysis sensory neurons. Proc Natl Acad Sci USA 87:2040-2044.

Byrne JH (1987) Cellular analysis of associative learning. Physiol Rev 67:329-439.

Byrne JH, Kandel ER (1996) Presynaptic facilitation revisited: state and time dependence. J Neurosci 16:425-435.

Castellucci V, Kandel ER (1976) Presynaptic facilitation as a mechanism for behavioral sensitization in Aplysia. Science 194:1176-1178.

Chavez-Noriega LE, Stevens CF (1994) Increased transmitter release at excitatory synapses produced by direct activation of adenylate cyclase in rat hippocampal slices. J Neurosci 14:310-317.

Chavez-Noriega LE, Halliwell JV, Bliss TVP (1990) A decrease in firing threshold observed after induction of the EPSP-spike (E-S) component 
of long-term potentiation in rat hippocampal slices. Exp Brain Res 79:633-641.

Chen C, Regher WG (1997) The mechanism of cAMP-mediated enhancement at a cerebellar synapse. J Neurosci 17:8687-8698.

Clark GA, Schuman EM (1992) Snails' tales: initial comparisons of synaptic plasticity underlying learning in Hermissenda and Aplysia. In: Neuropsychology of memory, Ed 2 (Squire LR, Butters N, eds), pp 588-602. New York: Guilford.

Clark GA, Hawkins RD, Kandel ER (1994) Activity-dependent presynaptic facilitation provides a cellular mechanism for the temporal specificity of classical conditioning in Aplysia. Learn Mem 1:243-258.

Collin C, Ikeno H, Harrigan JF, Lederhendler I, Alkon DL (1988) Sequential modification of membrane currents with classical conditioning. Biophys J 54:955-960.

Connor JA, Stevens CF (1971) Prediction of repetitive firing behavior from voltage clamp data on an isolated neurone soma. J Physiol (Lond) 213:31-53.

Coulter DA, Lo Turco JJ, Kubota M, Disterhoft JF, Moore JW, Alkon DL (1989) Classical conditioning reduces amplitude and duration of calcium-dependent afterhyperpolarization in rabbit hippocampal pyramidal cells. J Neurophysiol 61:971-981.

Crow TJ, Alkon DL (1980) Associative behavioral modification in Hermissenda: cellular correlates. Science 209:412-414.

Dale N, Kandel ER (1990) Facilitatory and inhibitory transmitters modulate spontaneous transmitter release at cultured Aplysia sensorimotor synapses. J Physiol (Lond) 421:203-222.

Dale N, Schacher S, Kandel ER (1988) Long-term facilitation in Aplysia involves increase in transmitter release. Science 239:282-285.

Delaney K, Tank DW, Zucker RS (1991) Presynaptic calcium and serotonin-mediated enhancement of transmitter release at crayfish neuromuscular junction. J Neurosci 11:2631-2643.

Disterhoft JF, CoulterDA, Alkon DL (1986) Conditioning-specific membrane changes of rabbit hippocampal neurons measured in vitro. Proc Natl Acad Sci USA 83:2733-2737.

Disterhoft JF, Golden DT, Read HL, Coulter DA, Alkon DL (1988) AHP reduction in rabbit hippocampus neurons during conditioning correlate with acquisition of the learned response. Brain Res 462:118-125.

Eichenbaum H (1996) Learning from LTP: A comment on recent attempts to identify cellular and molecular mechanisms of memory. Learn Mem 3:61-73.

Eliot LS, Hawkins RD, Kandel ER, Schacher S (1994) Pairing specific, activity-dependent presynaptic facilitation at Aplysia sensory-motor neuron synapses in isolated cell culture. J Neurosci 14:368-383.

Farley J (1988) Associative training results in persistent reductions in a calcium-activated potassium current in Hermissenda type B photoreceptors. Behav Neurosci 102:784-802.

Farley J, Alkon DL (1982) Associative neural and behavioral change in Hermissenda: consequences of nervous system orientation for light and pairing specificity. J Neurophysiol 48:785-807.

Farley J, Alkon DL (1987) In vitro associative conditioning of Hermissenda: cumulative depolarization of type B photoreceptors and shortterm associative behavioral changes. J Neurophysiol 57:1639-1668.

Farley J, Auerbach S (1986) Protein kinase C activation induces conductance changes in Hermissenda photoreceptors like those seen in associative learning. Nature 319:220-223.

Fost JW, Clark GA (1996) Modeling Hermissenda: I. Differential contributions of IA and and IC reductions to type-B cell plasticity. J Comput Neurosci 3:137-153.

Frysztak RJ, Crow T (1993) Differential expression of correlates of classical conditioning in identified medial and lateral type A photoreceptors of Hermissenda. J Neurosci 13:2889-2897.

Frysztak RJ, Crow T (1994) Enhancement of type B and A photoreceptor inhibitory synaptic connections in conditioned Hermissenda. J Neurosci 14:1245-1250.

Frysztak RJ, Crow T (1997) Synaptic enhancement and enhanced excitability in presynaptic and postsynaptic neurons in the conditioned stimulus pathway of Hermissenda. J Neurosci 17:4426-4433.

Ghirardi M, Braha O, Hochner B, Montarolo PG, Kandel ER, Dale N (1992) Roles of PKA and PKC in facilitation of evoked and spontaneous transmitter release at depressed and nondepressed synapses in Aplysia sensory neurons. Neuron 9:479-489.

Gingrich KJ, Byrne JH (1985) Simulation of synaptic depression, posttetanic potentiation, and presynaptic facilitation of synaptic potentials from sensory neurons mediating gill-withdrawal reflex in Aplysia. J Neurophysiol 53:652-659.

Gingrich KJ, Byrne JH (1987) Single-cell neuronal model for associative learning. J Neurophysiol 57:1705-1715.

Goldsmith BA, Abrams TW (1991) Reversal of synaptic depression by serotonin at Aplysia sensory neuron synapses involves activation of adenylyl cyclase. Proc Natl Acad Sci USA 88:9021-9025.

Goldsmith BA, Abrams TW (1992) cAMP modulates multiple $\mathrm{K}^{+}$currents, increasing spike duration and excitability in Aplysia sensory neurons. Proc Natl Acad Sci USA 89:11481-11485.

Goy M, Kravitz EA (1989) Cyclic AMP only partially mediates the actions of serotonin at the lobster neuromuscular junction. J Neurosci 9:369-379.

Hammer M, Cleary LJ, Byrne JH (1989) Serotonin acts in the synaptic region of the sensory neurons in Aplysia to enhance transmitter release. Neurosci Lett 104:235-240.

Hawkins RD (1981) Interneurons involved in mediation and modulation of gill-withdrawal reflex in Aplysia. III. Identified facilitating neurons increase $\mathrm{Ca}^{+2}$ current in sensory neurons. J Neurophysiol 45:327-339.

Hawkins RD, Abrams TW, Carew TJ, Kandel ER (1983) A cellular mechanism of classical conditioning in Aplysia: activity-dependent amplification of presynaptic facilitation. Science 219:400-405.

Hille B (1992) Ionic channels of excitable membranes, Ed 2. Sunderland, MA: Sinauer.

Hochner B, Kandel ER (1992) Modulation of a transient $\mathrm{K}^{+}$current in the pleural sensory neurons of Aplysia by serotonin and cAMP: implications for spike broadening. Proc Natl Acad Sci USA 89:11476-11480.

Hochner B, Klein M, Schacher S, Kandel ER (1986) Additional component in the cellular mechanism of presynaptic facilitation contributes to behavioral dishabituation in Aplysia. Proc Natl Acad Sci USA 83:8794-8798.

Hu GY, Storm JF (1991) Excitatory amino acids acting on metabotrophic glutamate receptors broadens the action potential in hippocampal neurons. Brain Res 568:339-344.

Isaac JTR, Nicoll RA, Malenka RC (1995) Evidence for silent synapses: implications for the expression of LTP. Neuron 15:427-434.

Kandel ER, Schwartz JH (1982) Molecular biology of learning: modulation of transmitter release. Science 218:433-443.

Klein M (1993) Differential cyclic AMP dependence of facilitation at Aplysia sensorimotor synapses as a function of prior stimulation: augmentation versus restoration of transmitter release. J Neurosci 13:159-166.

Klein M (1994) Synaptic augmentation by 5-HT at rested Aplysia sensorimotor synapses: Independence of action potential prolongation. Neuron 13:159-166.

Klein M, Kandel ER (1980) Mechanism of calcium current modulation underlying presynaptic facilitation and behavioral sensitization in Aplysia. Proc Natl Acad Sci USA 77:6912-6916.

Klein M, Shapiro E, Kandel ER (1980) Synaptic plasticity and modulation of the calcium current. J Exp Biol 89:117-157.

Laerum H, Storm JF (1994) Hippocampal long-term potentiation is not accompanied by presynaptic spike broadening, unlike synaptic potentiation by $\mathrm{K}^{+}$channel blockers. Brain Res 637:349-355.

Liao D, Hessler NA, Malinow R (1995) Activation of postsynaptically silent synapses during pairing-induced LTP in CA1 region of hippocampal slice. Nature 375:400-404.

Llinas RR (1991) Depolarization release coupling: an overview. Ann NY Acad Sci 635:3-17.

Matzel LD, Rogers R (1993) Postsynaptic calcium, but not cumulative depolarization, is necessary for the induction of associative plasticity in Hermissenda. J Neurosci 13:5029-5040.

Matzel LD, Lederhendler II, Alkon DL (1990) Regulation of short-term associative memory by calcium-dependent protein kinase. J Neurosci 10:2300-2307.

Matzel LD, Muzzio I, Rogers RF (1995) Complex current and voltage responses to baclofen in a molluscan photoreceptor. J Neurophysiol 74:506-518.

Matzel LD, Rogers RF, Talk AC (1996) Bidirectional regulation of neuronal potassium currents by the G-protein activator aluminum fluoride as a function of intracellular concentration. Neuroscience 74:1175-1185.

Matzel LD, Talk AC, Muzzio IA, Rogers RF (1998) Ubiquitous molecular substrates for associative learning and activity-dependent neuronal facilitation. Rev Neurosci 9:1-39.

Muzzio IA, Talk AC, Matzel LD (1997) Incremental translocation of 
protein kinase $\mathrm{C}$ underlies the acquisition "curve" during in vitro associative conditioning. Behav Neurosci 111:739-753.

Muzzio IA, Talk AC, Matzel LD (1998) Intracellular $\mathrm{Ca}^{2+}$ and adaptation of voltage responses to light in Hermissenda photoreceptors. NeuroReport 9:1625-1631.

Pieroni JP, Byrne JH (1992) Differential effects of serotonin, FMRFamide, and small cardioactive peptide on multiple, distributed processes modulating sensorimotor synaptic transmission in Aplysia sensory neurons. Proc Natl Acad Sci USA 87:2036-2039.

Pugliese AM, Ballarini L, Passani MB, Corradetti R (1994) EPSP-spike potentiation during primed burst-induced long-term potentiation in the CA1 region of rat hippocampal slices. Neuroscience 62:1021-1032.

Roberson ED, English JD, Sweatt JD (1996) A biochemist's view of long-term potentiation. Learn Mem 3:1-24.

Robitaille R, Charlton MP (1992) Presynaptic calcium signals and transmitter release are modulated by calcium-activated potassium channels. J Neurosci 12:297-305.

Rogers RF, Matzel LD (1995) Higer-order associative processing in Hermissenda suggests multiple sites of neuronal modulation. Learn Mem 2:279-298.

Sabatini BL, Regher WG (1997) Control of neurotransmitter release by presynaptic waveform at the granule cell to purkinje cell synapse. J Neurosci 17:3425-3435.

Sacktor TC, Schwarz JH (1990) Sensitizing stimuli cause translocation of protein kinase C in Aplysia sensory neurons. Proc Natl Acad Sci USA 87:2036-2039.

Schuman EM, Clark GA (1994) Synaptic facilitation at connections of Hermissenda type B photoreceptors. J Neurosci 14:1613-1622.

Stark LL, Carew TJ (1999) Developmental dissociation of serotonininduced spike broadening and synaptic facilitation in Aplysia sensory neurons. J Neurosci 19:334-346.

Stevens CF, Sullivan J (1998) Synaptic plasticity. Curr Biol 8: R151-R153.
Storm JF (1987) Phorbol esters broaden the action potential in CA1 hippocampal pyramidal cells. Neurosci Lett 75:71-71.

Sugita S, Goldsmith JR, Baxter DA, Byrne JH (1992) Involvement of protein kinase $\mathrm{C}$ in serotonin-induced spike broadening and synaptic facilitation in sensorimotor connections of Aplysia. J Neurophysiol 68:643-651.

Sugita S, Baxter DA, Byrne JH (1994) Activation of protein kinase C mimics serotonin-induced modulation of a voltage-dependent potassium current in pleural sensory neurons of Aplysia. J Neurophysiol 72:1240-1249.

Sugita S, Baxter DA, Byrne JH (1997) Differential effects of 4-aminopyridine, serotonin, and phorbal esters on facilitation of sensorimotor connections in Aplysia. J Neurophysiol 77:177-185.

Talk AC, Matzel LD (1996) Calcium influx and release from intracellular stores contribute differentially to activity-dependent neuronal facilitation in Hermissenda photoreceptors. Neurobiol Learn Mem 66:183-197.

Talk AC, Muzzio I, Matzel LD (1997) Phospholipases and arachidonic acid contribute independently to sensory transduction and associative facilitation in Hermissenda type B photoreceptors. Brain Res 751:196-205.

Trudeau L, Emery DG, Haydon PG (1996) Direct modulation of the secretory machinery underlies PKA-dependent synaptic facilitation in hippocampal neurons. Neuron 17:789-797.

Weisskopf MG, Castillo PE, Zalutsky RA, Nicoll RA (1994) Mediation of hippocampal mossy fiber long-term potentiation by cyclic AMP. Science 265:1878-1882.

West A, Barnes E, Alkon DL (1982) Primary changes of voltage responses during retention of associative learning. J Neurophysiol 48:1243-1255.

Yamoah EN, Crow TJ (1995) Evidence for a contribution of $\mathrm{I}_{\mathrm{Ca}}$ to serotonergic modulation of $\mathrm{I}_{\mathrm{K}, \mathrm{Ca}}$ in Hermissenda photoreceptors. J Neurophysiol 74:1349-1354. 